\title{
Field Study of Gravel Admix, Vegetation, and Soil Water Interactions: Protective Barrier Program Status Report - FY 1989
}
W. J. Waugh
L. L. Cadwell
M. E. Thiede
S. O. Link
C. J. Kemp

August 1990

Prepared for the U.S. Department of Energy under Contract DE-AC06-76RLO 1830

Pacific Northwest Laboratory

Operated for the U.S. Department of Energy

by Battelle Memorial Institute 


\title{
DISCLAIMER
}

This report was prepared as an account of work sponsored by an agency of the United States Government. Neither the United States Government nor any agency therenf, nor Battelle Memorial Institute, nor any of their employees, Inakes any warranty, expressed or implied, or assumes any legal liability or responsibility for the accuracy, completeness, or usefulness of any information, apparatus, product, or process disclosed, or represents that its we would not infringe privately owned rights. Reference herein to any specific commercial product, process, or service by trade name, trademark, manufacturer, or otherwise, does not necessarily constitute or imply its endorsement, recolnmendation, or favoring by the United States Government or any agency thereof, or Battelle Mernorial Institute. The views and opinions of authors expressed herein do not necessarily state or reflect those of the United States Government or any agency thereof.

\author{
PACIFIC NORTHWEST LABORATORY \\ operated by \\ BATTELLE MEMORIAL INSTITU־E \\ for the \\ UNITED STATES DEPARTMENT OF ENERGY \\ under Contract DE-AC06-76RLO 1830
}

Printed in the United States of Anerica

Avaidable w DOE and DOE contractors from the

Office of Scientific and Technical Information, P.O. Box 62, Oak Ridge, TN 37831; prices available from (615) 576-8401. FTS 626-8401.

Availabic to the publis from the National Teclunical Infermation Service, U.S. Deparment of Commerec, 5285 Pori Royal Rd,. Springfield, VA 22161.

N lis Price Codes, Mirrofiche A01

Printed Copy

\begin{tabular}{cr}
\hline Price Code & Page Range \\
\hline A02 & $1-10$ \\
A03 & $11-50$ \\
A04 & $51-75$ \\
A05 & $76-100$ \\
A06 & $101-125$ \\
A07 & $126-150$ \\
A06 & $151-175$ \\
A09 & $176-200$ \\
A10 & $201-225$ \\
A11 & $226-250$ \\
A12 & $251-275$ \\
A13 & $276-300$ \\
A14 & $301-325$
\end{tabular}

\begin{tabular}{cc}
\hline Price Code & Page Range \\
\hline A15 & $326-350$ \\
A16 & $351-375$ \\
A17 & $376-400$ \\
A18 & $401-425$ \\
A19 & $426-450$ \\
A20 & $451-475$ \\
A21 & $476-500$ \\
A22 & $501-525$ \\
A23 & $526-550$ \\
A24 & $551-575$ \\
A25 & $576-600$ \\
A99 & $601-U p$
\end{tabular}


PNL-7440

UC-702

FIELD STUDY OF

GRAVEL ADMIX, VEGETATION, AND

SOIL WATER INTERACTIONS:

PROTECTIVE BARRIER PROGRAM

STATUS REPORT - FY 1989

\author{
W.J. Waugh \\ M.E. Thiede \\ C.J. Kemp \\ L.L. Cadwell \\ S.O. Link
}

August 1990

Prepared for

the U.S Department of Energy

under Contract DE-AC06-76RLO 1830

Pacific Northwest Laboratory

Richland, Washington 99352 


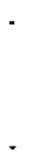




\section{EXECUTIVE SUMMARY}

Pacific Northwest Laboratory (PNL) and Westinghouse Hanford Company (Westinghouse Hanford) are collaborating on a field study of the effects of gravel admixtures on plant growth and soil water storage in protective barniers. Protective barriers are engineered earthern covers designed to prevent water, plants, and animals from contacting buried waste and transporting contaminants to groundwater or the land surface. Some of the proposed designs include gravel admixtures or gravel mulches on the barrier surface to control soil loss by wind and runoff.

The purpose of this study is to measure, in a field setting, the influence of surface gravel additions on soil water storage and plant cover. The study plots are located northwest of the Yakima Gate in the McGee Ranch old field. Here we report the status of work completed in FY 1989 on 1) the creation of a data management system, 2) a test of water application uniformity, 3) field calibration of neutron moisture gages, and 4) an analysis of the response of plants to various combinations of gravel admixtures and increased rainfall.

The data management system was set up on the PNL H-VAX to establish consistent field data collection procedures, document and verify computer data entries, and standardize data analysis and graphics programs. Data acquired and entered routinely include monthly precipitation, enhanced rainfall (irrigation), monthly neutron moisture probe readings, and semi-annual plant cover measurements.

Irrigation uniformity was measured as part of an evaluation of the water application procedure. Water is applied monthly to half of the study plots using a conventional irrigation system. The purpose of the irrigation treatment is to simulate the combined effects of surface gravel admixtures and a wetter climate on plant growth and soil water storage. The irrigation amount is calculated as the difference between twice the monthly average rainfall and the ambient rainfall recorded at the Hanford Meterological Station. To test uniformity we placed collection cans on study plots using a stratified random sampling design and then applied about $4 \mathrm{~mm}$ of water. We found little difference between the volumes of water collected at the center and at the perimeter of plots. However, plots closer to 
the pump received more water than plots farther away from the pump. Improvements in the water application procedure are recommended, accordingly.

Wet and dry test plots were constructed for a linear regression calibration of the neutron hydroprobes that have been used during the course of the study. The hydroprobes are used to monitor water storage changes. The calibration data consisted of paired neutron counts and water content (mass basis) at several depths within the test plots and soil bulk density to convert water content to volume units. We found that calibration functions did not change significantly with depth, and therefore, a single calibration will be used for each probe. These calibrations are needed for analyses of treatment effects on soil water storage.

The effect of gravel admixtures on plant gowth is a key issue in designing protective barriers. Gravel may be necessary to curb soil loss, especially during dry years when vegetation alone may be inadequate. However, if the gravel layer is too thick, it may increase water infiltration, retard evaporation, inhibit plant establishment, and thus restrict the cycling of water back into the atmosphere. By comparison, a thin gravel veneer or a gravel admixture may enhance plant growth and thus improve barrier water relations.

Plant cover has been sampled twice yearly for 3 years using an ocular pointintercept instrument. Plant species composition and cover were no different on plots with gravel admix than on plots without gravel. However, a more diverse species composition established on plots irrigated with twice the annual precipitation than on non-irrigated plots and plant cover was greater. These findings are in agreement with the preliminary results of a companion study in which the effects of a variety of surface treatments on plant biomass and soil water balance are measured in lysimeters. 


\section{CONTENTS}

EXECUTIVE SUMMARY $\ldots \ldots \ldots \ldots \ldots \ldots \ldots \ldots \ldots \ldots \ldots \ldots \ldots \ldots \ldots \ldots$ iii

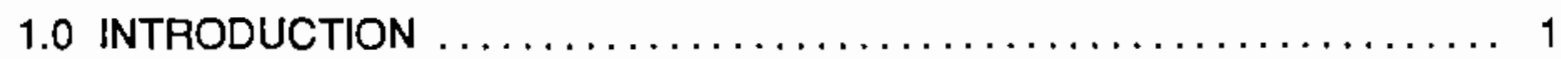

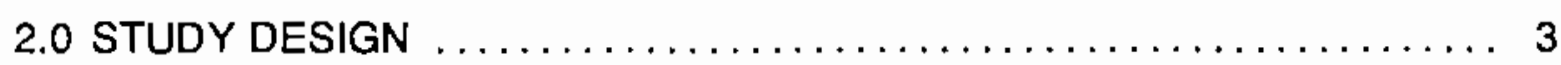

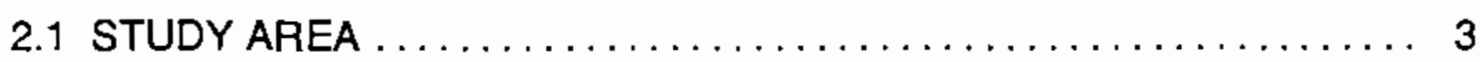

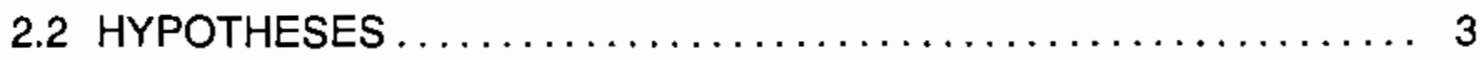

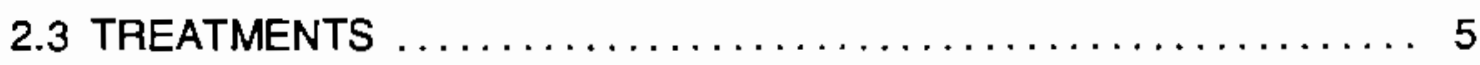

2.3.1 Gravel Admixtures .............................. 6

2.3.2 Vegetation $\ldots \ldots \ldots \ldots \ldots \ldots \ldots \ldots \ldots \ldots \ldots \ldots \ldots \ldots \ldots \ldots, 6$

2.3.3 Precipitation Enhancernent ....................... 8

2.4 EXPERIMENTAL DESIGN $\ldots \ldots \ldots \ldots \ldots \ldots \ldots \ldots \ldots \ldots \ldots \ldots$

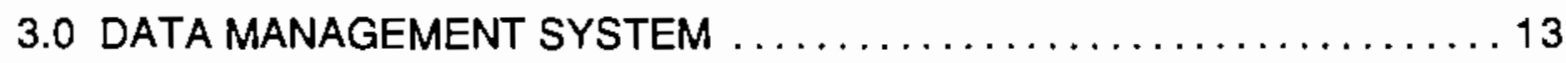

4.0 IRRIGATION RECORD AND UNIFORMITY $\ldots \ldots \ldots \ldots \ldots \ldots \ldots \ldots \ldots \ldots \ldots \ldots \ldots$

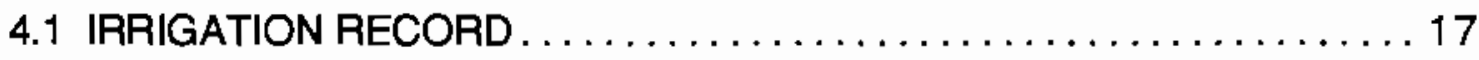

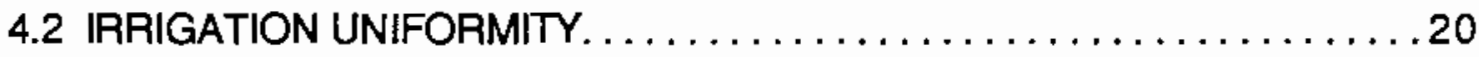

5.0 NEUTRON HYDROPROBE FIELD CALIBRATION $\ldots \ldots \ldots \ldots \ldots \ldots .23$

5.1 METHODS $\ldots \ldots \ldots \ldots \ldots \ldots \ldots \ldots \ldots \ldots \ldots \ldots \ldots \ldots \ldots \ldots \ldots \ldots \ldots, 23$

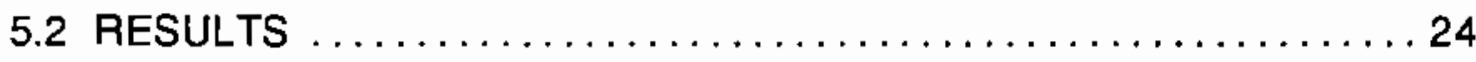

6.0 PLANT COVER RESPONSES. ........................... 29

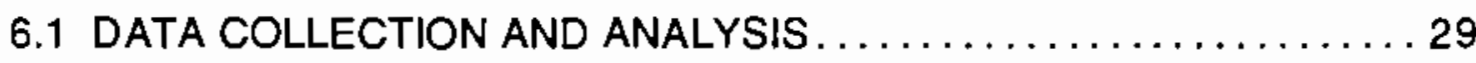

6.2 RESULTS AND DISCUSSION .......................... 30

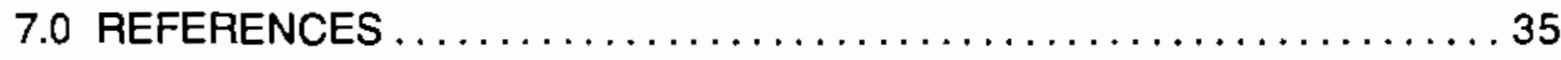




\section{EIGURES}

2.1 Locations of the Gravel Admix Field-Plot Experiment .............. 4

2.2 Split-Split-Plot Design Structure for the Gravel Admix Field Experiment .. 10

3.1 Schematic Drawing of the Gravel Admix Field-Plot Experiment Data Management System .............................. 14

4.1 Sprinkler Irrigation System for the Gravel Admix Field Experiment . . . . . 18

4.2 Irrigation Sampling Strata on a Whole Plot in Relation to the Spray Pattern and the Position of Neutron Hydroprobe Access Welts ........ 21

5.1 Calibration Curves for the Ripped Zone and Below the Ripped Zone for the Westinghouse Hanford Company Neutron Hydroprobe ........ 25

5.2 Field Calibration for the Westinghouse Hanford Company Neutron Hydroprobe ................................... 26

5.3 Field Calibration for the Pacific Northwest Laboratory Neutron Hydroprobe .................................. 27

5.4 Field Calibration for the New Westinghouse Hanford Company Neutron Hydroprobe

6.1 Percentage Cover by Cover Class (Total Vegetation, Agropyron Species, Bromus tectorum, Salsola kali, and Gravel) tor 1987, 1988, and 1989 in Plots that were Treated with $15 \%, 30 \%$, or No Gravel Admixture and then Either Irrigated or Not irrigated.

6.2 Dry Weight Biomass of Cheatgrass for May 1989 in Lysimeters Treated with $30 \%$ Gravel Admixture, an Equivalent Amount of Surface Gravel Mulch, or No Gravel, and then Either Irrigated at a Rate Twice the Long-Term Average Precipitation or Not Irrigated. 


\section{IABLES}

2.1 Treatment Structure for the Gravel Admix Field Experiment .......... 5

2.2 Composition of Seed Mixture Sown and Fertilizer Spread on Gravel Admix Test Plots at McGee Ranch . ................ 8

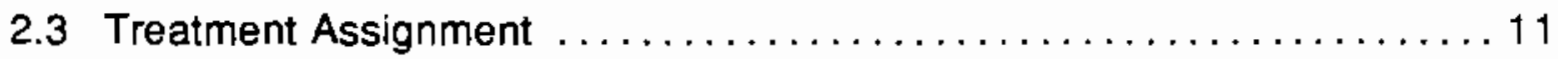

4.1 Imigation and Precipitation Record for the McGee Admix Field Plots, August 1987 through July $1989 \ldots \ldots \ldots \ldots \ldots \ldots \ldots \ldots \ldots \ldots$

4.2 Water Captured in Collection Cans for a Stratified Random Sampling

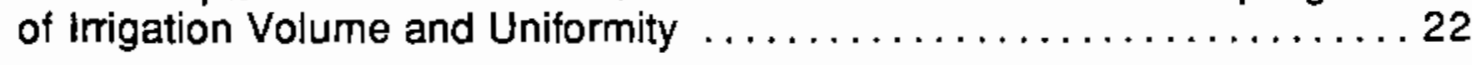

5.1 Gravimetric Water Content and Dry Weight Bulk Density of Soils in the Neutron Hydroprobe Field Calibration Plots at McGee Ranch ......... 25 
• 


\subsection{INTRODUCTION}

Pacific Northwest Laboratory (PNL) and Westinghouse Hanford Company (Westinghouse Hanford) are working jointly to develop earthen protective barriers for the near-surface disposal of radioactive and hazardous wastes at Hanford. Large volumes of wastes are currently stored at Hanford in a variety of near-surface waste burial facilities. Demonstration of a defensible protective barnier that isolates buried waste from environmental transport would offer planners an attractive alternative to the more costly option of exhuming and hauling wastes to a deep geologic repository. A multi-year research program is under way to assess the long-term performance of protective barriers in preventing water, plants, and animals from contacting buried waste and transporting contaminants to the groundwater or to the land surface. This program has been charged with demonstrating that barriers will satisfy established performance criteria for 10,000 years without monitoring, maintenance, or other institutional controls.

The proposed barrier design consists of a blanket of fine-textured soil overlying a sequence of layers grading from sand to coarse gravel (USDOE 1987). The fine-textured topsoil stores rainwater until it can be cycled back into the atmosphere by evaporation and plant transpiration. This layered configuration is based on a principle of soil physics called the Richards effect (Richards 1931), which suggests that water will be stored in the soil layer and not pass into the sand and gravel layers until the soil at the layer interface is virtually saturated. Reduction in the thickness of the topsoil by excessive erosion could lower its capacity to store water and result in unacceptable rates of water movement into underlying wastes. Several studies funded by the Hanford Site Protective Barrier Development Program are under way to test surface additions of gravel mulches and admixtures for long-term control of wind and runoff erosion (Ligotke 1989; Walters et al. 1990). Incorporation of gravel into the surface of the barrier topsoil is intended to mimic conditions that led to the formation of desert pavements that have remained stable for thousands of years.

Although adding gravel to the barrier topsoil may control erosion, it may also compromise the capacity of a barier to cycle water back into the atmosphere. The addition of surface gravel to arid land soils can increase water infiltration, reduce the water storage capacity, and yield fewer grasses and more shrubs and forbs 
(Nichols et al. 1984). Thereiore, the Hanford Site Protective Barrier Development Program includes studies to measure the effects of gravel additions on soil water storage, surface evaporation, water drainage through the barrier, plant abundance, and plant water extraction (Waugh and Link 1987; Link and Waugh 1989; Ge日 et al. 1989).

Here we report the status of work conducted in FY 1989 on a field-plot study of the influence of gravel admixtures on soil water storage and plant abundance (Waugh and Link 1987). Included in the report are 1) descriptions of the experimental design; 2) a description of the data management system set up for the project; 3) the results of a water application uniformity test, which is part of a wetter climate treatment in the experiment; 4) the results of a field calibration of neutron moisture gages; and 5) the results of a 3-year analysis of the response of plants to various combinations of gravel admixtures and supplemental water. 


\subsection{STUDY DESIGN}

\subsection{STUDY AREA}

The gravel admix field-plot experiment was installed in the fall of 1986 at McGee Ranch on the Hanford Site (Figure 2.1). McGee Ranch lies directly northwest of the Yakima Barricade in Section 20, Township 13 North, Range 25 East, and is bordered on the south and east by Washington State Highway SR24. McGee Ranch was chosen in 1986, following reconnaissance and soil testing (Myers 1987), as a source of topsoil for protective barrier experiments and ultimately for the full-scale construction of barriers at Hanford.

The study area is part of an abandoned agricultural field that was flood irrigated before 1944 when the Hanford Site was created as part of the Manhattan Project. Irrigation rills transecting the old field from the northeast to the southwest are still visible. The vegetation of adjacent untilled tracts consists of an association of sagebrush (Artemisia tridentata) and spiny hopsage (Gravia spinosa). The old field remains dominated by cheatgrass (Bromus tectorum); however, Russian knapweed (Centaurea repens) has rapidly increased in abundance over the last few years.

The soil at McGee Ranch is a thick silt loam formed in slackwater sediments deposited during periods of cataclysmic Pleistocene flooding. A very weak eluvial clay layer and a thick calcareous layer occur at a depth of about $50 \mathrm{~cm}$. The average annual precipitation, as recorded at the Hanford Meteorological Station approximately 5 miles east, is $15.0 \mathrm{~cm}$ (Stone et al. 1983). Peak precipitation is in January with a secondary peak in June.

\subsection{HYPOTHESES}

This study addresses the question: What effects do surface gravel admixtures have on plant establishment, growth, and soil water storage? The experiment was designed to test the following null hypotheses:

1) Additions of gravel to the topsoil layer of the protective barrier, for erosion control, would have no effect on plant species composition or abundance. 


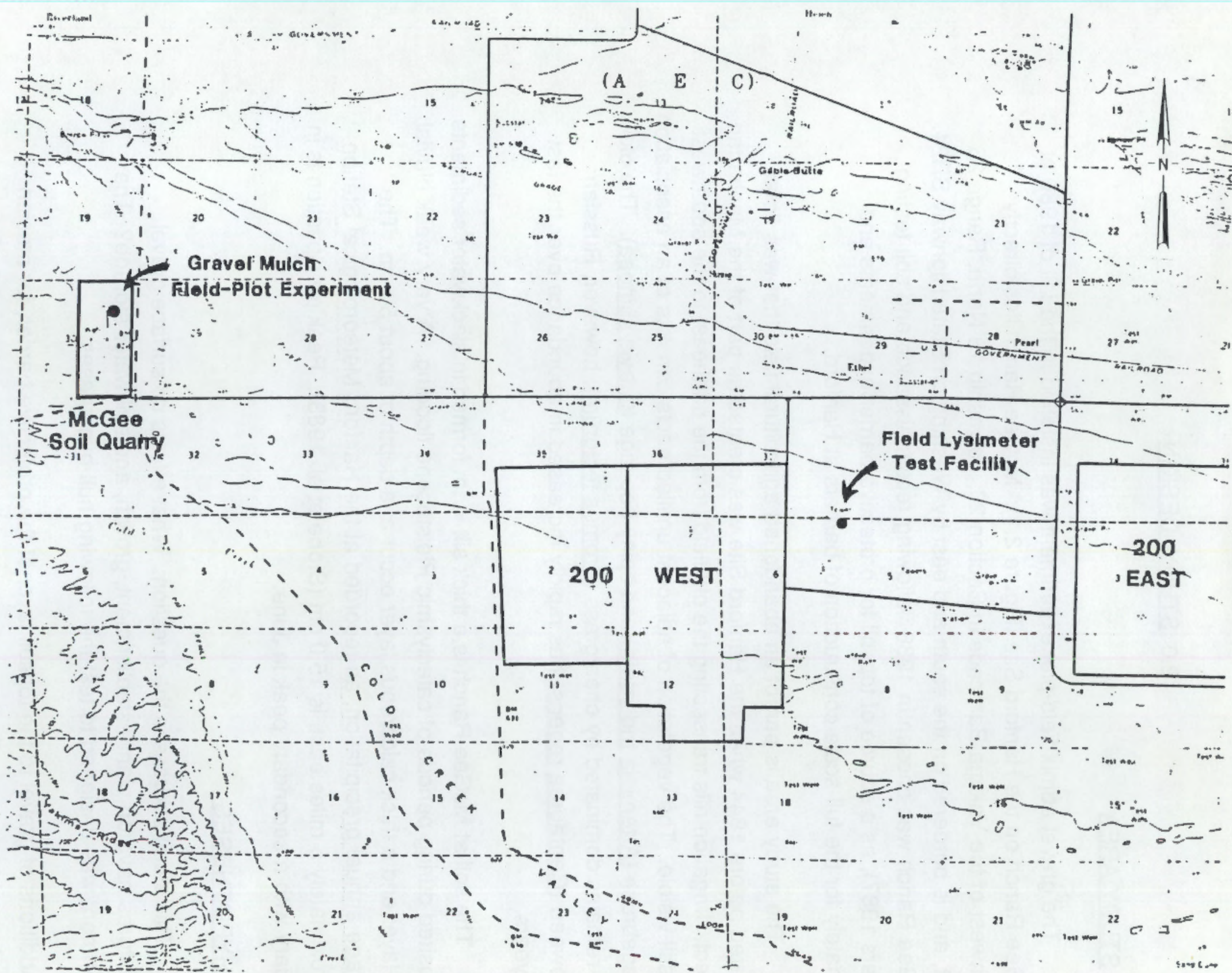

FIGURE 2.1. Locations of the Gravel Admix Field-Plot Experiment 
2) Additions of gravel to the topsoil layer of the protective barrier would not increase water storage with or without the presence of vegetation.

3) Doubling the annual precipitation, as a future wetter climate scenario, would have no effect on plant species composition or abundance.

4) Doubling the annual precipitation would not increase water storage with or without the presence of vegetation.

Four components of the experimental design are defined: the treatment structure, the design structure, the method of assigning treatments to experimental units in the design structure, and the statistical model dictated by the total design (Milliken and Johnson 1984).

\subsection{IREATMENTS}

The study consists of a three-way factorial treatment structure encompassing three levels of gravel admix, two levels of vegetation, and two levels of irrigation (Table 2.1).

IABLE2.1. Treatment Structure for the Gravel Admix Field Experiment(a)

$\begin{array}{ll}\frac{\text { Factor }}{\text { Gravel }} \frac{\text { Levels }}{3} & \begin{array}{l}\text { Treatment Description } \\ \text { 1. } 15 \% \text { by wt gravel admix to a depth of } 20 \mathrm{~cm}\end{array} \\ & \text { 2. } 30 \% \text { by wt gravel admix to a depth of } 20 \mathrm{~cm}\end{array}$

Vegetation 2 1. Native and exotic grass/shrub seed mix

2. Control: nonselective herbicide

Water $\quad 2 \quad 1.2 \times$ normal monthly precipitation

2. Control: no supplemental water

(a) 12 treatment combinations $\times 3$ replications $=36$ experimental units. 


\subsubsection{Gravel Admixtures}

Two concentrations of $1.0-\mathrm{cm}$-diameter pea gravel, $15 \%$ and $30 \%$ by wt mixed with soil to a depth of $20 \mathrm{~cm}$, were included in the study for tests of hypotheses 1 and 3. Fifteen percent gravel admix was included for comparison with past model predictions. Fayer et al. (1985) used $15 \%$ pea gravel in an UNSAT-H computer model simulation of the effects of gravel on recharge. The simulations indicated that in silt loam soil like the McGee soils, and without vegetation, $15 \%$ gravel mixed to depths of $7.5 \mathrm{~cm}$ or deeper would cause $1.7 \mathrm{~cm}$ drainage during an average precipitation year. The simulations also indicated that no drainage would occur with vegetation present, regardless of soil type. We speculated that $15 \%$ would be insufficient for erosion control, so we doubled it for the second level. Results of wind tunnel tests have since indicated that $30 \%$ pea gravel may be the optimum selection (Ligotke 1989). Pea gravel has a higher surface-area-to-volume ratio than larger gravel or cobble and thus may provide greater soil protection with less impact on soil hydraulic properties. Wind erosion essentially ceases on desert pavements as the surface area covered by stones approaches 50\% (Mabbutt 1977).

A gravel admixture (mixed with soil) rather than a surface gravel mulch was selected because, like a desert pavement below which stones remain dispersed in the soil, an admixture could provide a degree of self-healing following disturbances of the surface veneer. Also, a surface gravel mulch may eventually resemble an admixture as a product of the balance of pedoturbation (natural soil mixing) and erosional and depositional processes.

\subsubsection{Vegetation}

Vegetation may be an essential component of the protective barrier. Plants curb soil loss and can enhance deposition. Higher plants feed soil microorganisms and promote soil aggregation, secondary mineralization, and hence, moisture retention and soil stability. Perhaps of greater importance, plants extract water from the barrier. Most of the precipitation entering the soil in arid and semiarid regions of North America is returned to the atmosphere via transpiration from plants and 
evaporation from soil--evapotranspiration (ET) (Evans et al. 1981). What is not lost by $E T$ and runoff is stored in the soil or lost as subsurface drainage below the root zone. It is generally assumed that little or no drainage occurs under arid conditions (Evans and Thames 1981). However, significant quantities of water can be lost to deep drainage if the soil is coarsely textured (low in silt and clay content). Under this condition, water readily moves through the soil, particularly during times when little evapotranspiration occurs. If plant roots are inactive, or if the soil texture is coarse enough that the percolating water moves below the root zone, water becomes available for deep drainage. Therefore, if we change the barrier topsoil-the plant habitat--to simulate deposition or to control erosion, we will need to know how these changes may influence plant water extraction.

A stable and lasting plant community cannot be engineered, unlike other components of the protective barrier. Plant communities are dynamic and, to some degree, unpredictable. Over time, regardless of what is initially seeded, a plant community will likely converge with that which would have developed naturally. The natural development or succession of a plant community generally leads to greater biomass, slowed biogeochemical cycling, a buffering of macroenvironmental impacts (such as the effect of precipitation on soil water movement) and greater site stability (Odum 1969). With this in mind, the objective of the vegetation treatment was to accelerate succession--to establish a plant community with attributes similar to those of the community that would develop over time naturally.

The two vegetation treatment levels for the study comprised a mixture of native and exotic plant species (Table 2.2) and bare soil. The following types of species were included in the mixture: 1 ) indigenous species found in mature plant communities at McGee Ranch and surrounding the 200 areas, 2) commercially available cultivars similar to native species for which cultivars were not available, and 3) relatively easy to establish cultivars similar to more difficult to establish native species. To minimize initial interspecific competition and provide an optimum seedbed ecology, some species were seeded with a tractor-drawn "Truax" drill while others were broadcasted with a hand-operated cyclone spreader. Fertilizer (16N:20P: OK) was broadcasted, with boot hoses, disconnected from the small box on the drill. Following the seeding operation, plots were compacted and pitted with a cultipacker. The benefits of this practice include fertilizer incorporation, seedbed water conservation, improved seed-to-soil contact, and variable seed-depth placement. 
TABLE 2.2. Composition of Seed Mixture Sown and Fertilizer Spread on Gravel Admix Test Plots at McGee Ranch

\section{Species}

Drill-Seeded

Siberian wheatgrass

(Agropyron sibericum)

Thickspike wheatgrass

(Agropyron dasystachyum)

Indian ricegrass

(Oryzopsis hymenoides)

\section{Broadcast-Seeded}

Big sagebrush

(Artemisia tridentata)

Rabbitbrush

(Chrysothamnus nauseosus)

Antelope bitterbush

(Purshia tridentata)

Spiny hopsage

(Grayia spinosa)

Canaby bluegrass

(Poz canbvi)

Sheep fescue

(Festuca ovina)

Eertilizer (16-20-0)

$\mathrm{N}$

$P$
Cultivar or

Subspecies

P-27

Critana

Nezpas

Tridentata

Albicaulis

-- Oregon

Idaho

Canbar

Covar

$-$

Source

Idaho

Idaho

Idaho

Idaho
86

84

59

$7 / 81$

Colorado 9

$1 / 80$

0.7

0.8

9.7

2.9

6.1

84

$6 / 85$

$\begin{array}{ll}-- & - \\ - & -\end{array}$

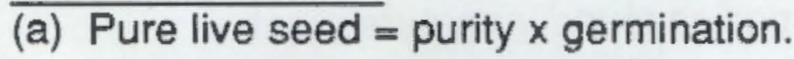

Placement of seed at variable depths helps balance the germination of a diverse species mixture.

\subsubsection{Precipitation Enhancement}

The purpose of the precipitation enhancement treatment was to simulate the combined effects of a wetter climate and gravel admix on soil water storage and plant abundance (hypotheses 3 and 4). For comparative experiments, simulating a 
wetter climate is generally limited to water applications. To simulate natural conditions, the water application equipment would ideally permit close control of the frequency, timing, intensity, and uniformity of artificial rainfall, as well as the amount. Such a setup would require, at a considerable cost, automated rainfall simulators and mobile plot "umbrellas" linked by computer to a real-time, meterological data logger. A conventional sprinkler system designed with as uniform a spray pattern as possible was used instead. Irrigation amount is calculated as the difference between twice the monthly average rainfall and the ambient amount measured at the Hanford Meteorological Station.

The historical annual precipitation at Hanford ranges from 8 to $27 \mathrm{~cm}$ with a mean of $16.0 \mathrm{~cm}$ (Stone et al. 1983). Using extreme value statistics, Kinnison (1983) estimated the maximum 100-year annual precipitation to be $30.1 \mathrm{~cm}$. This value has been used in performance assessment calculations and in all wetter year model simulations of drainage through protective barriers. Although not defensible as a 10,000-year worst case condition, $32 \mathrm{~cm}$, or double the mean annual precipitation, was selected as the wet climate treatment. No supplemental water is the control. These values are consistent with treatments in the Hanford Site Protective Barrier Development Program lysimeter experiments (Kirkham and Gee 1987; Waugh and Link 1987).

\subsection{EXPERIMENTAL DESIGN}

The design structure of an experiment consists of experimental units grouped so that treatments are observed under as uniform conditions as possible. Each of the 12 treatment combinations described above were replicated three times, totaling 36 field plots, in a classic split-split-plot (SSP) treatment design structure (Figure 2.2). Each of six large 10- $\times 15-\mathrm{m}$ whole plots were divided into six 5- $\times 5-\mathrm{m}$ subplots in a $2 \times 3$ grid. Treatments were assigned to these plots in the following hierarchy: Each whole plot received a precipitation enhancement level; a vegetation level was randomly assigned to half of a whole plot (the split-plot treatment); and the levels of gravel were randomly assigned to the subplots within the split plots (the SSP treatments). Table 2.3 shows the assignment of treatments to field plots.

Split-plot and SSP designs are often used when physical conditions make it difficult to completely randomize a factorial experimental design. 


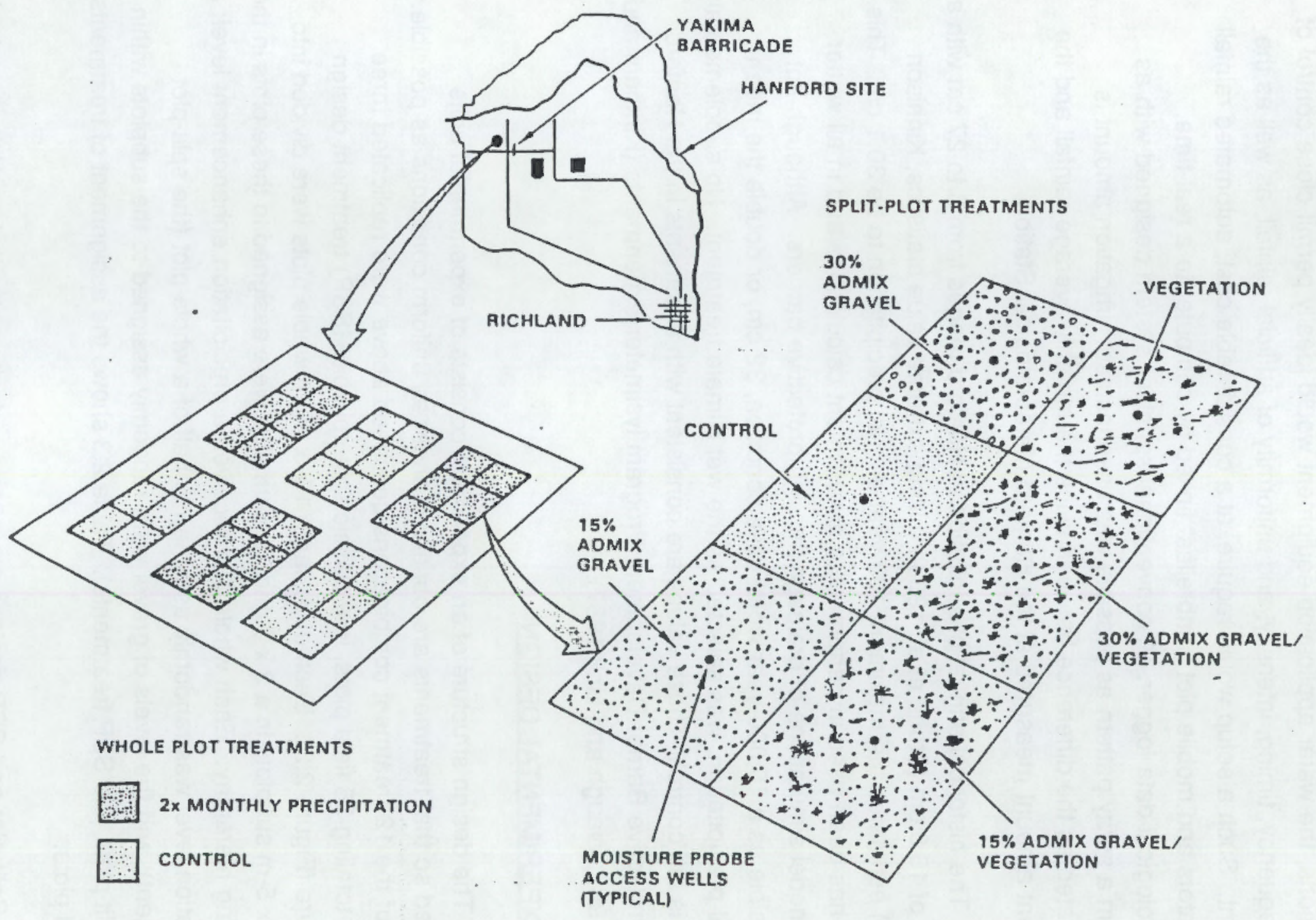

FIGURE 2.2. Split-Split-Plot Design for the Gravel Admix Field Experiment 


\section{IABLE 2.3. Treatment Assignment}

Plot

Number

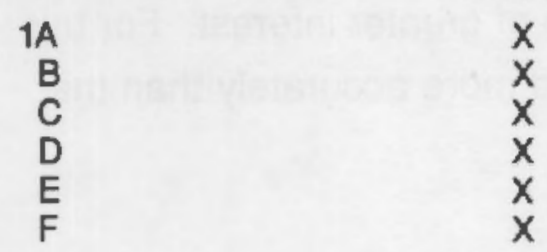

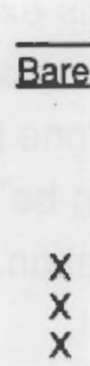

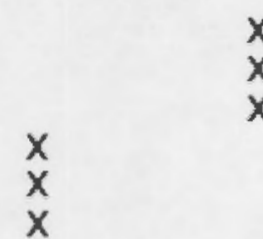

$\hat{x}$

$x$
$x$
$x$
$x$
$x$
$x$

$x$
$x$
$x$
$x$
$x$
$x$

$5 A$

B

C

D

$\mathrm{F}$

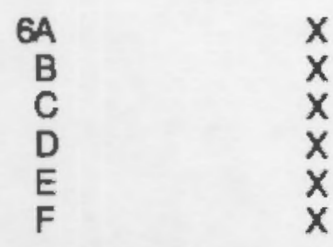

Veaetation

$x$

$\mathrm{x}$

$\mathrm{x}$
$\mathrm{x}$

$x$
$x$
$x$

$x$

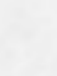

$x$
$x$

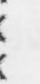

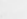

$\mathrm{x}$

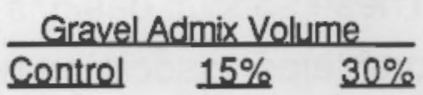

$x$

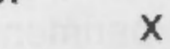

$\mathrm{X}$

$x$

$\mathrm{x}$

$\mathbf{x}$

$\stackrel{x}{x}$

$x$

$x$

$x$

$x$

$\mathrm{x}$

$x$

$\mathbf{x}$

$\mathrm{X}$

$x$

$\underset{x}{x}$

$\mathrm{X}$

$x$

$x$

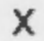

$\mathrm{x}$

$\mathrm{x}$
$\mathrm{x}$
$\mathrm{x}$

$x$
$x$

$x$

$x$

$x$
$x$
$x$

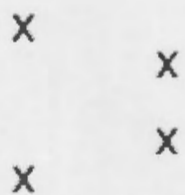

(a) Natural rainfall.

(b) Twice the average annual precipitation recorded at the Hanford Meteorological Station. 
These special designs were chosen for this experiment because of logistical problems associated with randomly irrigating and drill seeding small plots. These designs are also used when the effects of one factor are of greater interest. For this experiment, the effects of gravel admix can be estimated more accurately than the effects of vegetation or enhanced precipitation. 


\subsection{DATA MANAGEMENT SYSTEM}

The gravel admixture field-plot study at McGee Ranch was designed to produce a wide variety of data over a period of several years. These data are expensive to collect; therefore, the better they are documented, the more likely they are to be useful to scientists and engineers working on the Hanford Site Protective Barrier Development Program in the future. To this end, a centralized database management system (Figure 3.1) has been established on the PNL H-VAX computer located in the LSL II building in the main Battelle complex. The system consists of five basic components: 1) standardized data collection forms designed to encourage recorders to consistently enter all essential field information; 2) consistent data entry into the computer and quality-controlled data verification; 3) data coding, sorting, and restructuring programs to make it accessible to analysis and graphics programs; 4) data graphics programs; and 5) data analysis programs. All programs are written in the SAS system language for data management and analysis (SAS Institute 1985). The system is accessible by modem or direct link to PNL and Westinghouse Hanford users across the Hanford Site for graphics and analysis in SAS, or for importing to mini- and microcomputer operating systems.

The data acquired on a routine basis for the McGee gravel admixture study include the following:

- monthly rainfall amount from the Hanford Meteorological Station

- irrigation volume applied

- monthly neutron probe field-plot counts and standard counts

- plant cover data recorded as point-intercept hits.

All field data records are stored in a QA Level III project file in Room 35, Building 331, 300 Area. The project file custodian is L.L. Cadwell. The neutron probe and plant cover data are transferred to the H-VAX, and probe count data are entered on separate files for each sampling session. After editing and entry verification, files for different sampling sessions are merged into a single file for analysis and graphics. This composite file can be accessed as follows:

Directory DISK1:[TULE.MCGEE] file: MGPROBE.DAT 


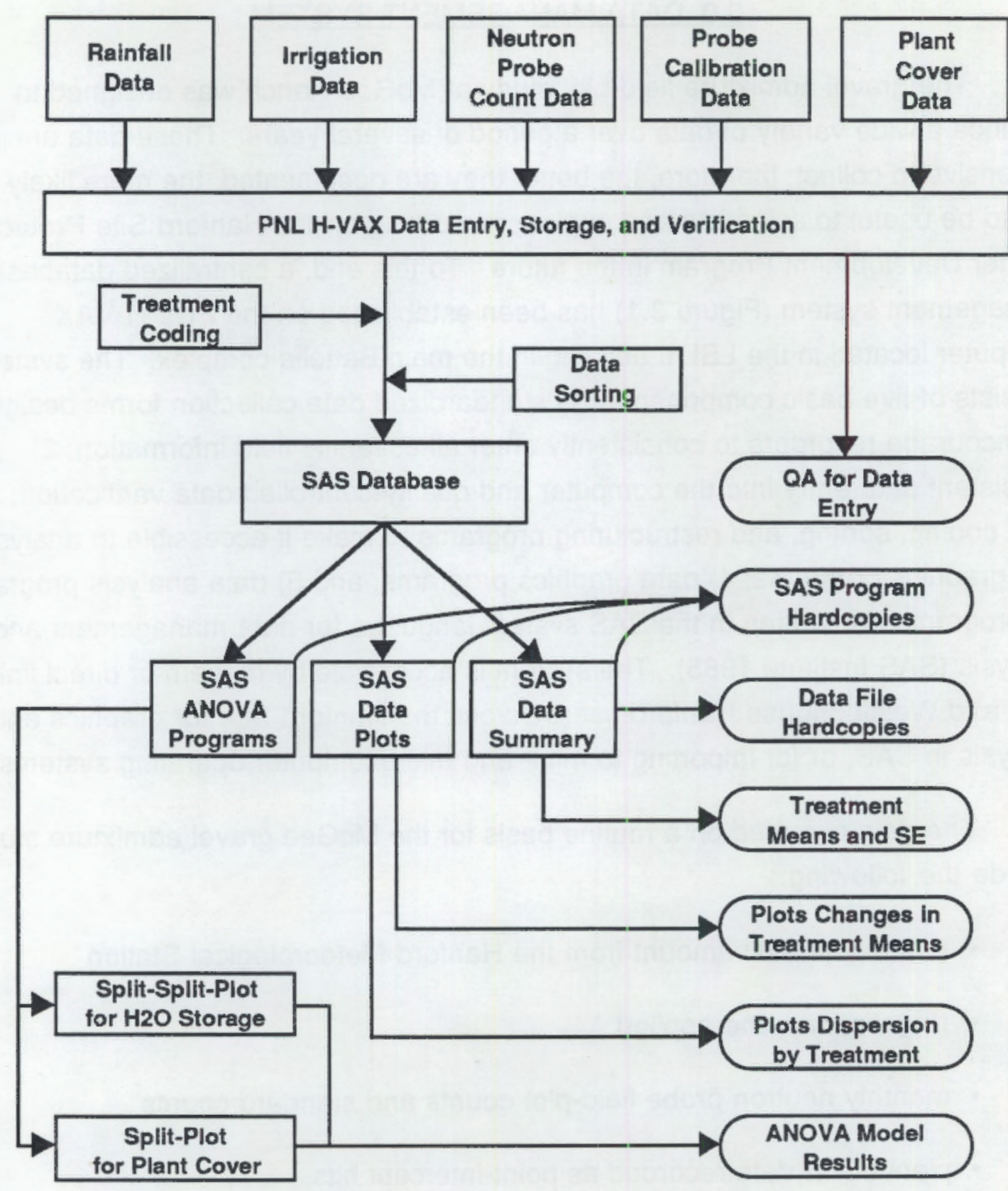

ElGURE 3.1. Schematic Drawing of the Gravel Admix Field-Plot Experiment Data Management System 
Files are printed after each entry and checked by a second technician. Data entry and verification personnel record their initials and the date of work in the following $Q A$ file:

Directory DISK1: [TULE.QA] file: summary.dsc

After raw neutron probe count data and plant cover data are read into the SAS file, the program assigns one of 12 treatment combinations (Table 2.1) and a replicate number to each plot. Plots are coded as to whether they receive ambient or twice average precipitation, as vegetated or bare, and by the surface cover $(0$, 15 , or $30 \%$ admix). Sampling times are converted to Julian calendar days and SAS time to assist in graphing. Data are then transposed by attaching treatment qualifiers so that each data point is uniquely identified.

Neutron probe standard counts, measured at the beginning and end of each monthly sampling session, are entered in a separate file. The data are standardized using a count ratio to remove dritt in probe electronics and changes in environmental influences between sampling sessions. Each field-plot count is divided by the mean of 20 standard counts taken in the probe housing or in another invariant medium. Counts are converted to percent water content $\left(\mathrm{cm}^{3} / \mathrm{cm}^{3}\right)$ using linear regression coefficients derived from a field calibration (Section 5.0).

Several SAS programs were written for processing plant cover data. Plant cover data are entered as the number of species "hits" recorded using an ocular point-intercept method. The programs collectively 1) convert the hit data to singlelayer percent cover; 2) sort the cover data by species, season, and date; 3 ) calculate mean and standard error statistics for various combinations of species for each season; and 4) test for treatment effects on plant cover using a reduced splitplot analysis of variance model (Waugh and Link 1987). 



\subsection{IRRIGATION RECORD AND UNIFORMITY}

Water is applied to whole plots 1,3 , and 5 with a conventional irrigation system to test gravel admix effects on plant abundance and on water storage under conditions of a wetter climate (Section 2.2). The system was layed out with spray heads positioned to apply water in a uniform pattern (Figure 4.1). In 1989, we secured a new source of irrigation water. Between May 1987 and July 1989, Columbia River water was hauled to the site by tanker truck to refill a 2500-gal holding tank at McGee Ranch. In July, we installed a water line between nearby McGee Well and the hoiding tank, approximately $100 \mathrm{~m}$ away. Previously sealed at the depth of the Artesian aquifer, the McGee Well was restored in 1989 by the Basalt Waste isolation Project (BWIP). Water quality data, acquired from BWIP, are stored in the project file. The state of Washington granted the study a water right exemption because of the small volumes used to refill the holding tank.

\subsection{IRRIGATION RECORD}

The irrigation amount is calculated as the difference between twice the monthly average rainfall, from Hanford Meteorlogical Station records, and the ambient rainfall for that month. This information, plus the amount of water applied since 1987 , the total monthly combined rainfall and irrigation, and the cumulative monthly amounts, are shown in Table 4.1.

The conventional irrigation system at McGee Ranch differs from natural rainfall patterns in some important ways. Depending on the frequency of water applications, the lag time between the period during which natural precipitation is recorded and the following catch-up irrigation session may force a seasonally artificial delay in plant growth and animal behavior responses. Applying water significantly out of synchrony with the phenology and seasonal behavior of plants and animals could confound interpretations of the effects of a wetter climate on the soil water balance. For example, water applied in July, to double the April average rainfall, might percolate past dead cheatgrass roots that in April would have returned it to the atmosphere. Water applications for the twice average treatment at McGee Ranch lag ambient rainfall by 1 month. Water is applied as soon as possible the following month to minimize ecophysiological perturbations. 


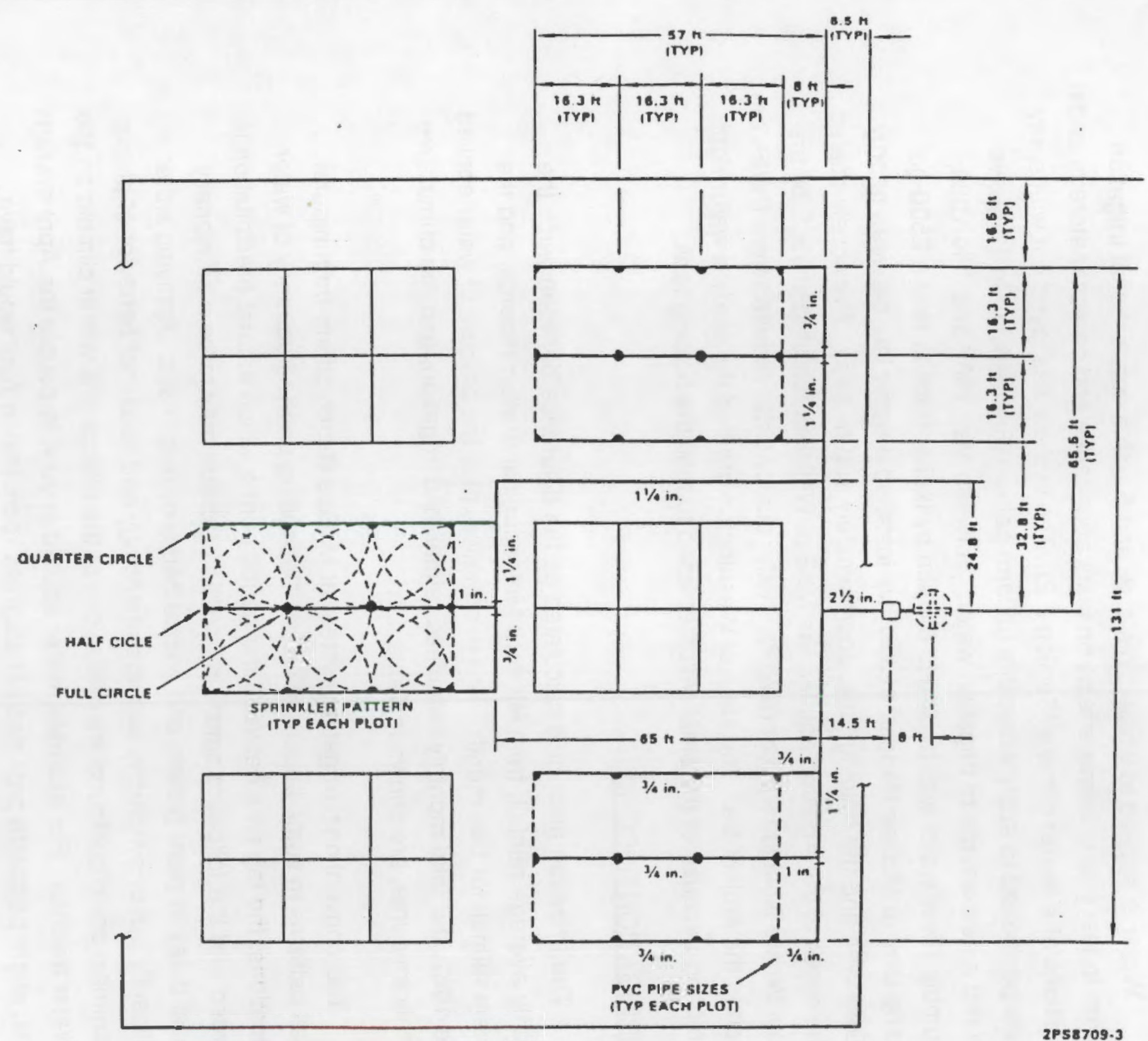

FIGURE 4.1. Sprinkler Irrigation System for the Gravel Admix Field Experiment 
TABLE 4.1. Irrigation and Precipitation Record for the McGee Admix Field Plots, August 1987 through July 1989

\begin{tabular}{|c|c|c|c|c|c|c|}
\hline Date & $\begin{array}{c}\text { Monthly(a) } \\
\text { Average } \\
\text { Precipitation } \\
\text { (mm) } \\
\end{array}$ & $\begin{array}{c}\text { HMS } \\
\text { Recorded } \\
\text { Precipitation } \\
\text { (mm) } \\
\end{array}$ & $\begin{array}{c}\text { MoGee } \\
\text { Admix } \\
\text { Irrigation } \\
\text { (mm) } \\
\end{array}$ & $\begin{array}{l}\text { McGee (b) } \\
\text { Irrigation } \\
\text { Volume } \\
\text { (L) } \\
\end{array}$ & $\begin{array}{c}\text { Total } \\
\text { Water } \\
\text { Received } \\
\text { (mm) }\end{array}$ & $\begin{array}{c}\text { Cumulative } \\
\text { Water } \\
\text { Received } \\
\text { (mm) }\end{array}$ \\
\hline $8 / 87$ & 6.1 & 1.8 & 0.2 & 87.8 & 2.0 & 2.0 \\
\hline $9 / 87$ & 7.9 & 0.3 & 11.2 & 5046.6 & 11.5 & 13.4 \\
\hline $10 / 87$ & 14.2 & 0.0 & 15.9 & 7139.5 & 15.9 & 29.3 \\
\hline $11 / 87$ & 21.6 & 10.2 & 0.0 & 0.0 & 10.2 & 39.5 \\
\hline $12 / 87$ & 22.6 & 41.4 & 0.0 & 0.0 & 41.4 & 80.9 \\
\hline $1 / 88$ & 23.4 & 12.2 & 0.0 & 0.0 & 12.2 & 93.1 \\
\hline $2 / 88$ & 15.2 & 0.0 & 0.0 & 0.0 & 0.0 & 93.1 \\
\hline $3 / 88$ & 9.4 & 9.9 & 25.8 & 11602.7 & 35.7 & 128.7 \\
\hline $4 / 88$ & 9.9 & 28.4 & 58.2 & 26190.3 & 86.6 & 215.4 \\
\hline $5 / 88$ & 12.2 & 8.4 & 13.7 & 6159.6 & 22.1 & 237.5 \\
\hline $6 / 88$ & 13.7 & 2.8 & 63.1 & 28418.8 & 65.9 & 303.4 \\
\hline $7 / 88$ & 3.8 & 3.3 & 22.9 & 10292.6 & 26.2 & 329.6 \\
\hline $8 / 88$ & 6.1 & 0.0 & 10.1 & 4524.7 & 10.1 & 10.1 \\
\hline $9 / 88$ & 7.9 & 9.9 & 0.0 & 0.0 & 9.9 & 20.0 \\
\hline $10 / 88$ & 14.2 & 0.3 & 0.0 & 0.0 & 0.3 & 20.2 \\
\hline $11 / 88$ & 21.6 & 20.8 & 18.5 & 8333.4 & 39.3 & 59.6 \\
\hline $12 / 88$ & 22.6 & 10.2 & 0.0 & 0.0 & 10.2 & 69.7 \\
\hline $1 / 89$ & 23.4 & 5.3 & 0.0 & 0.0 & 5.3 & 75.1 \\
\hline $2 / 89$ & 15.2 & 42.4 & 0.0 & 0.0 & 42.4 & 117.5 \\
\hline $3 / 89$ & 9.4 & 39.6 & 0.0 & 0.0 & 39.6 & 157.1 \\
\hline $4 / 89$ & 9.9 & 21.3 & 0.0 & 0.0 & 21.3 & 178.4 \\
\hline $5 / 89$ & 12.2 & 15.0 & 51.2 & 23019.9 & 66.1 & 244.6 \\
\hline $6 / 89$ & 13.7 & 0.3 & 37.0 & 16630.9 & 37.2 & 281.8 \\
\hline $7 / 89$ & 3.8 & 0.3 & 30.9 & 13902.3 & 31.1 & 312.9 \\
\hline
\end{tabular}

(a) Composite of Hanford Townsite and Hanford Meteorological Station (HMS) Records, 1912-1980.

(b) Volume passing through an in-line irrigation flow meter.

Irrigation rate (intensity) and daily timing are also important variables. Runoff will occur if irrigation rates exceed the saturated soil conductivity. Even the slightest runoff on a plot can result in nonuniform infiltration. Watering in the evening or early in the morning comes closer to simulating the surface energy balance of a cloudy, rainy day than watering at midday when the solar elevation, and thus insolation, are greatest. The gravel admix plots are typically irrigated early in the morning, and to prevent excessive runoff, the system is shut off at the first sign of ponding and reactivated several minutes later after infiltration has occurred. 
Irrigation uniformity, both within and among plots, is perhaps the most critical irrigation control variable because this study is first a comparative experiment, and second, a model validation experiment (lysimeter experiments will provide the principal model validation data). A high variability among plots in the volume of water applied would increase the probability of a Type-II error in the analysis. In other words, the hypothesis that gravel and vegetation have no effect on soil water content could be erroneously accepted in a situation where uneven irrigation causes a high variance that masks real differences. An irrigation specialist was consulted to aid in designing the McGee system with as uniform a spray pattern as possible with conventional sprinklers.

\subsection{IRRIGATION UNIFORMITY}

Irrigation uniformity was first measured in 1987 (Waugh 1989). The mean volume collected from cans placed randomly on the irrigated whole plots $(1,3$, and 5 ) was only $5.8 \%$ less than that measured with a flow meter. The difference was attributed to evaporation or spray drift. Of concern was the high variation observed within whole plots. The test was repeated in June 1989 using stratified random sampling. Strata 1 was defined as a 2- $\times 2-m$ area centered on each neutron hydroprobe access well, and strata 2 as the remaining perimeter area (Figure 4.2). Four collection cans (I.D. $=14.45 \mathrm{~cm} ; \mathrm{I} . \mathrm{H} .=14.51 \mathrm{~cm}$ ) were positioned on each subplot, two cans in strata 1, and two cans in strata 2, using randomly generated coordinates, for a total of 72 cans on whole plots 1,3 , and 5 . The volume equivalent of $3.8 \mathrm{~mm}$ rainfall $(60.07 \mathrm{cu} \mathrm{ft})$ was applied. The volume of water captured in the cans was recorded.

The results of the irrigation uniformity test (Table 4.2) show that the volume of water captured in collection cans near the hydroprobe wells (strata 1) and that captured in collection cans around the plot perimeters (strata 2) were not significantly different. However, significant differences were measured among whole plots in the amount of water captured $(p<0.05)$. Whole plot number 1 received the most water andwhole plot number 5 the least. Overall, $22 \%$ of the water passing through the system's flow meter during this test was lost to evaporation or drift. 


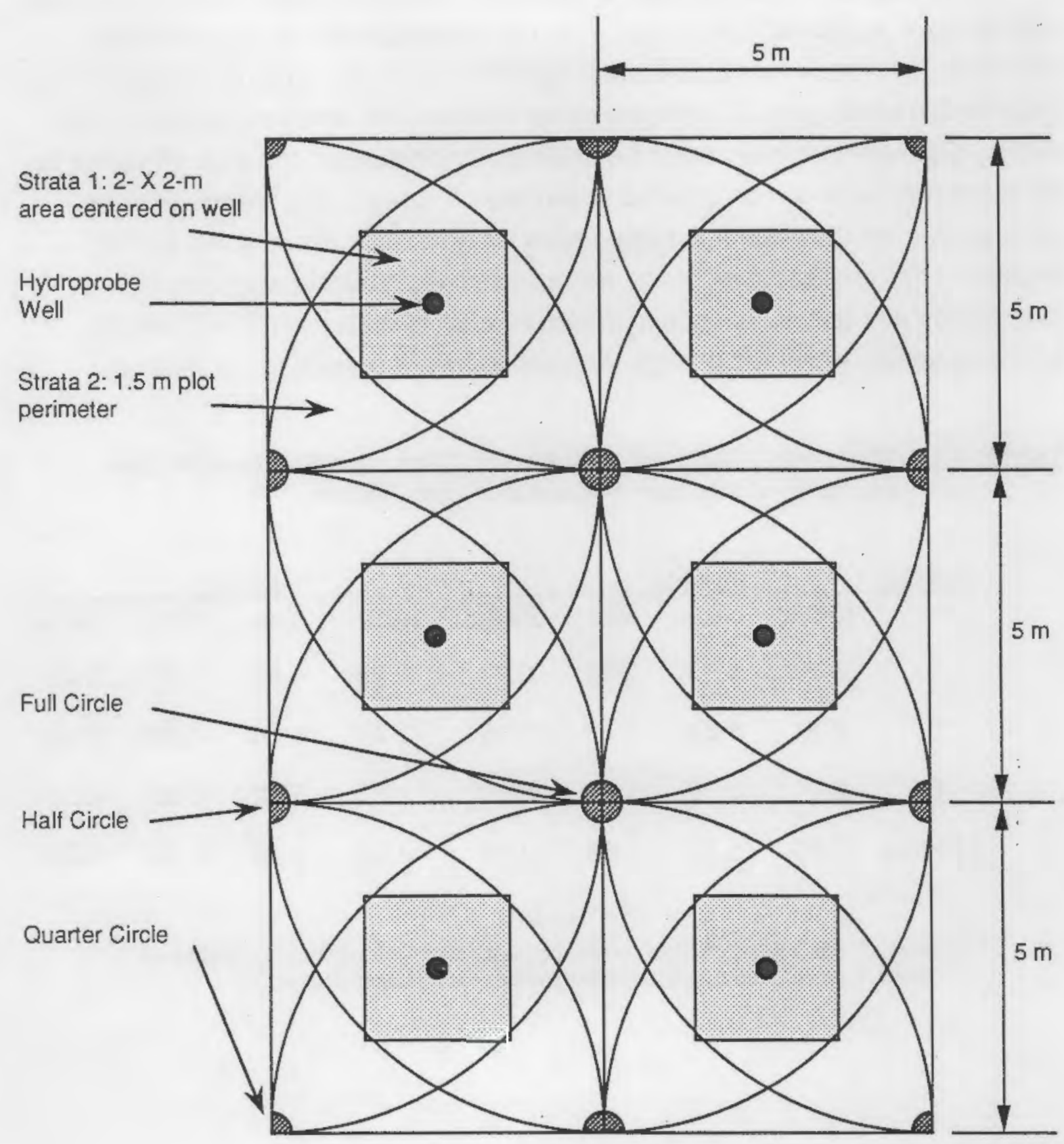

FIGURE 4.2. Irrigation Sampling Strata on a Whole Plot in Relation to the Spray Pattern and the Position of Neutron Hydroprobe Access Wells 
The results of this test suggest that some changes in the irrigation procedure may improve application uniformity, while other changes may not be warranted. Until now, the three whole plots were irrigated concurrently. The results of the test indicate that plots 1 and 3 , which are closer to the purnp, receive more water than plot 5. Equivalent volumes could be applied by manipulating the shut-off valves in the system so plots can be irrigated separately. Increasing the volume of water pumped through the system to compensate for water lost, based solely on the findings of this one test, may not be warranted. The amount of water lost to evaporation and dritt is dependent on factors such as air temperature, humidity, and wind speed, which will change from one irrigation session to the next.

IABLE 4.2. Water ( $\mathrm{mm}$ ) Captured in Collection Cans for a Stratified Random Sampling of Irrigation Volume and Uniformity(a)

Plot No.

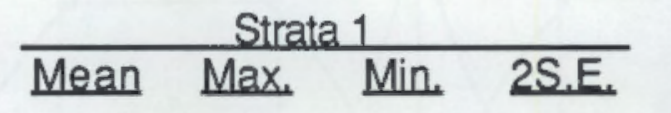

Strata2
Mean Max. Min. 2S.E.

1

$$
3.37
$$

5.73

2.32

0.28

2.93

4.45

1.65

0.24

3

2.81

3.84

1.83

0.16

3.48

6.28

0.73

0.48

5

2.37

3.66

1.65

0.20

2.83

5.12

0.85

0.39

All Plots

5.73

1.65

0.14

3.08

6.28

0.73

0.22

(a) Strata 1 was a 2- $\times 2$ 2-m area centered on each neutron hydroprobe access well. Strata 2 was the remaining perimeter area of each subplot (Figure 3.1). 


\subsection{NEUTRON HYDROPROBE FIELD CALIBRATION}

Neutron moisture probes are used to test of the effects of gravel admixtures and a wetter climate on soil water storage (hypotheses 2 and 4 in Section 2.1). The probe consists of a fast neutron source (AM-241/Be), a slow neutron detector, a lead and paraffin shield for absorbing harmful gamma rays and neutrons, and a digital readout unit attached to the shield. High-energy neutrons emitted by the source are slowed and scattered by the surrounding soil. Because hydrogen in soil water slows neutrons, which are then counted by the detector, the probe can be calibrated to provide a measure of soil water content. This section describes the methods and results of a field calibration of three hydroprobes that have been used for monthly monitoring of water storage in the McGee field plots. The standards required to transfer the field calibration from one probe to another are also presented.

\subsection{METHODS}

Two pairs of 2- $\times 2-\mathrm{m}$ plots were established within the boundaries of the area that was ripped during the construction of the McGee admix field study (Waugh 1989). A 20-cm berm was raised around the perimeter of one of each plot pair. Two $m$ lengths of aluminum tubing were installed at the center of each of the four calibration plots (see Waugh 1989, for tubing specifications and installation methods). Water was ponded on the bermed plots for 2 weeks. During the irrigation period, and thereafter until the plots were sampled, the wet plots were kept covered with plastic and wood to reduce evaporative loss. One week after the irrigation was discontinued, when it was assumed that the wet plots had drained to field capacity, five 16 -sec readings were taken with the PNL probe (CPN $\mathrm{H} 30103489$ ) and the new Westinghouse Hanford probe (CPN H39078966), and five 30-sec counts were taken with the old Westinghouse Hanford probe (CPN $\mathrm{H} 38092510$ ). Counts were taken in the access tubes at depths of $30,45,80,125$, and $175 \mathrm{~cm}$. Also, before and after counts were read in the calibration plots, 20 standard counts were taken with each probe properly latched in its housing, the housing situated on the probe carrying case, and the carrying case resting at a predetermined spot on the ground. 
After the neutron hydroprobe readings were taken in a calibration plot, soil samples were obtained around the access tube to determine gravimetric water content and soil bulk density. Pits were excavated around the access tube to the $30-\mathrm{cm}$ depth. Within this excavation, four core samples were extracted about $5 \mathrm{~cm}$ from the access tube and on opposite sides of the tube in north-south and eastwest directions, and sealed in labeled, airtight containers. The excavation was then enlarged to a uniform depth of $45 \mathrm{~cm}$, and four more core samples were obtained and sealed in airtight containers. This process was repeated at depths of 80,125 , and $175 \mathrm{~cm}$, and repeated for each calibration plot. Samples were ovendried at $105^{\circ} \mathrm{C}$ for at least 24 hours, reweighed, and mass-basis water contents calculated in accordance with Gardner (1986). In one pit, a piston-type soil volume sampler was used to extract $10 \mathrm{~cm}^{3}$ cores for determining soil bulk density (Blake and Hartge 1986). Five replicate cores were extracted from horizontal shelves cut into the pit wall at $30-, 80-$, and $125-\mathrm{cm}$ depths. Volurne-basis water content was obtained from the mass-basis water content and bulk density data (Gardner 1986).

\subsection{RESULTS}

Gravimetric water content data, bulk density data, and calibration functions for three neutron hydroprobes that have been used during the course of study are shown in Table 5.1 and Figures 5.1, 5.2, 5.3, and 5.4. Mean volumetric water contents for four core samples extracted at the each depth were paired with the appropriate mean count ratios in linear regression calibrations. Count ratios consist of the mean counts $(n=5)$ for a given calibration plot and depth as the numerator, and the mean shielded counts $(n=20)$ as the denominator. Each calibration function combines the values for all depths in the four calibration plots. Although the ripped zone ( 0 to $80 \mathrm{~cm}$ deep) was less compacted than the profile below the ripped zone ( $125 \mathrm{~cm}$ deep) (Table 5.1), the slopes of the regression functions for these two depths were insignificant (Figure 5.1). Therefore, a separate calibration for the ripped layer was determined to be unnecessary. The estimated coefficients of determination $\left(r^{2}\right)$ for the calibrations--the proportion of the variation in water content attributable to a linear relationship with the count ratio--all exceeded 0.90 . 
IABLE 5.1. Gravimetric Water Content $(\mathrm{g} / \mathrm{g})$ and Dry Weight Bulk Density $\left(\mathrm{g} / \mathrm{cm}^{3}\right)$ of Soils in the Neutron Hydroprobe Field Calibration Plots at McGee Ranch

\begin{tabular}{|c|c|c|c|c|c|c|c|c|c|}
\hline \multirow{3}{*}{$\begin{array}{l}\text { Depth } \\
\text { (cm) }\end{array}$} & \multicolumn{7}{|c|}{ Calibration Plot Water Content. $n=4(\mathrm{a} / \mathrm{a})$} & \multirow{2}{*}{\multicolumn{2}{|c|}{$\begin{array}{c}\text { Density, } n=5 \\
\left(0 / \mathrm{cm}^{3}\right)\end{array}$}} \\
\hline & WetPlot 1 & WetP & t2 & Dry & et 1 & DryPls & & & \\
\hline & Mean SE & Mean & $\underline{\mathrm{SE}}$ & Mean & SE & Mean & SE & Mean & SE \\
\hline 30 & 23.88 & 28.17 & 1.73 & 3.05 & 0.13 & 3.43 & 0.57 & 1.47 & 0.05 \\
\hline 45 & 22.03 & 20.65 & 2.05 & 2.67 & 0.03 & 3.56 & 0.17 & & \\
\hline 80 & 21.58 & 29.50 & 2.98 & 3.73 & 0.13 & 3.85 & 0.19 & 1.45 & 0.03 \\
\hline 25 & 23.13 & 20.08 & 1.14 & 3.67 & 0.12 & 4.43 & 0.27 & 1.56 & 0.01 \\
\hline 75 & 13.26 & 19.54 & 1.98 & 4.46 & 0.52 & 8.72 & 0.22 & & \\
\hline
\end{tabular}

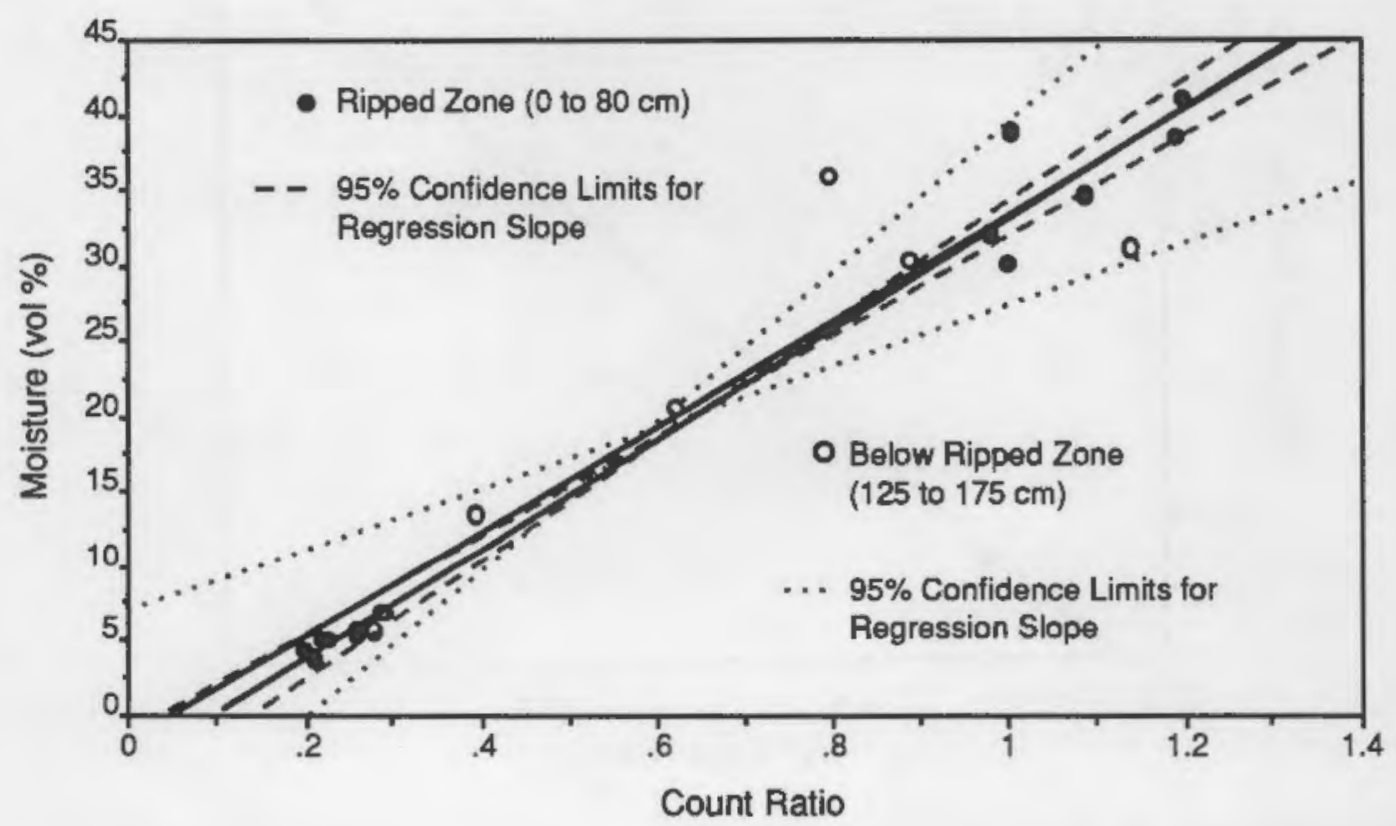

EIGURE 5.1. Calibration Curves for the Ripped Zone and Below the Ripped Zone for the Westinghouse Hanford Company Neutron Hydroprobe (CPN H38092510) 
In FY 1990, these calibrations will be used in analyses of treatment effects on soil water storage. Because the field calibrations were done simultaneously for all three of the probes that have been used for this study, transfer functions, typically required to transfer the calibration of one probe to another, will not be needed. If a different probe is used in the future, or if the Westinghouse Hanford probe now in use is returned to the manufacturer for repairs or is refitted with new components, a transfer function will be needed. The transfer function should be calculated using count data taken in the wet and dry standards located at the Arid Land Ecology Reserve headquarters before and after the repair work. Equivalent volumetric soil water contents would be assigned to the wet and dry standards based on the field calibration.

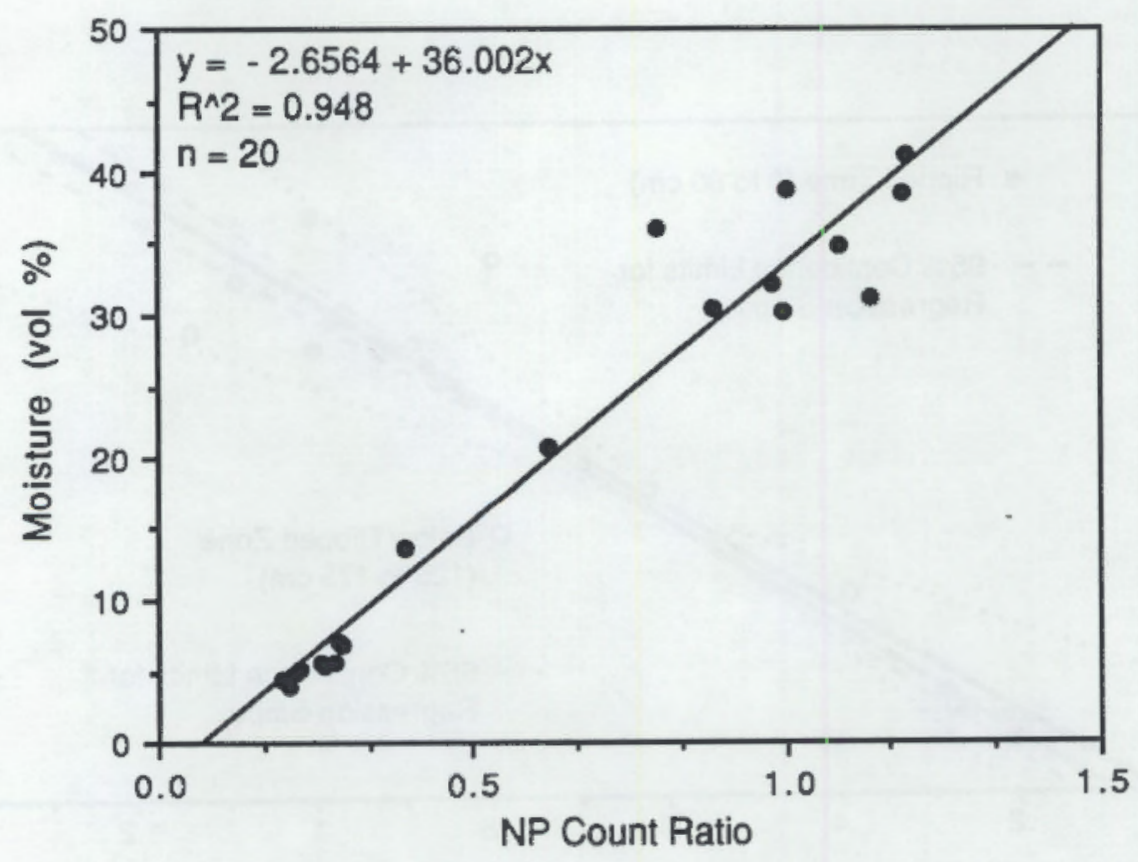

FIGURE 5.2. Field Calibration for the Westinghouse Hanford Company Neutron Hydroprobe (CPN H38092510) 


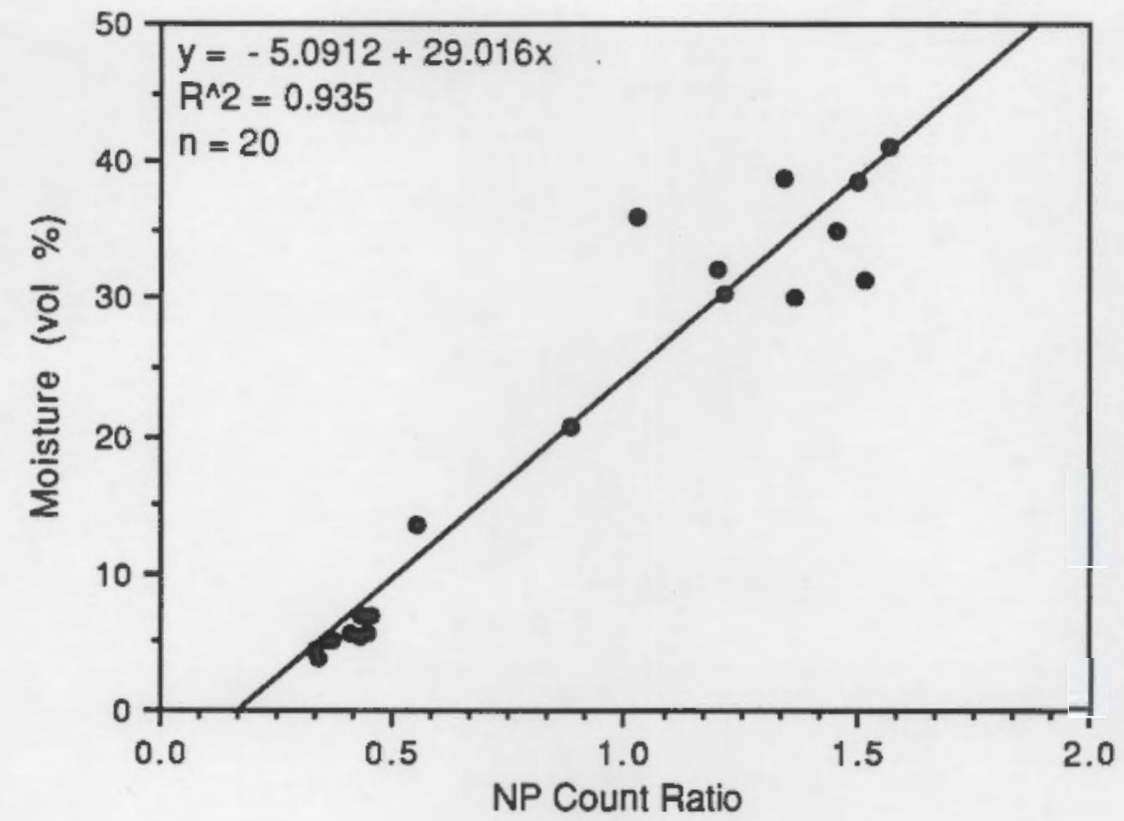

FIGURE 5.3. Field Calibration for the Pacific Northwest Laboratory Neutron Hydroprobe (CPNH30103489)

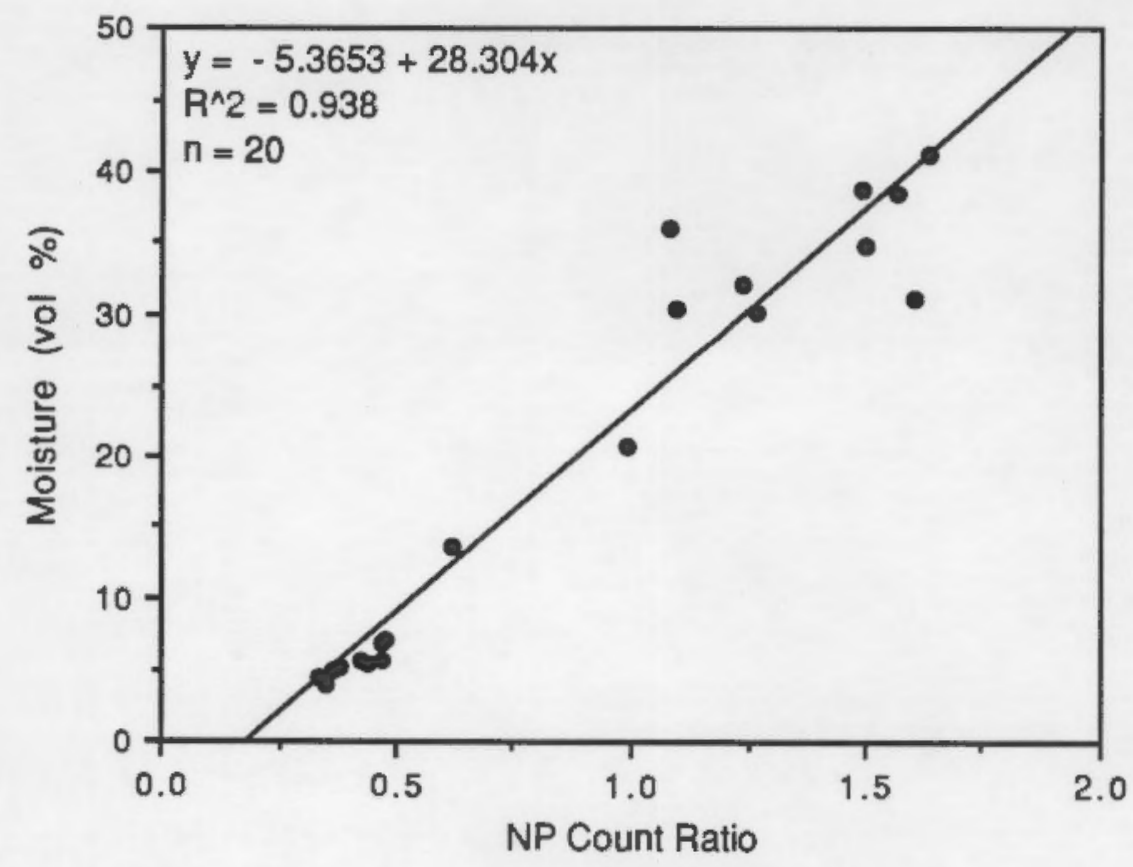

FIGURE 5.4. Field Calibration for the New Westinghouse Hanford Company Neutron Hydroprobe (CPN H39078966) 



\subsection{PLANT COVER RESPONSES}

The effect of gravel admixtures on plant growth is a key issue in designing protective barriers. Gravel mulches can protect against soil erosion, especially during dry years when vegetation alone may be inadequate to stabilize the surface. However, if the gravel layer is too thick, it will increase water infiltration, retard evaporation, inhibit vegetation establishment, and thus restrict the cycling of water back into the atmosphere. By comparison, a thin gravel veneer or a gravel admixture can enhance plant growth, and thus improve barrier water relations if consideration is given to the ecological tolerances of local species. In this section, we report the effects of various combinations of gravel admixtures and water applications on plant cover after 3 years of sampling. Section 2.0 provides a more detailed discussion of the role of vegetation as a component of the protective barrier design.

\subsection{DATA COLLECTION AND ANALYSIS}

Plant canopy cover has been sampled every spring and fall since 1987 using an ocular point-intercept sighting instrument (Floyd and Anderson 1983). The instrument consists of two $50-\times 100-\mathrm{cm}$ frames (inside dimensions) constructed with $5-\times 2-\mathrm{cm}$ maple lumber and separated by $10-\mathrm{cm}$ lengths of metal tubing. The frames were strung with white line in holes drilled at $10-\mathrm{cm}$ intervals to produce two 36-point sighting grids. This unit is mounted on three adjustable camera tripod legs so it can be raised and lowered to match the height of the plant canopy. Crosshairs of intersecting string in the above grid, when aligned with crosshairs at the same position on the lower grid, form a sighting point. Percent cover is estimated as the proportion of points (hits) that intercept plant species or other surface components of interest (gravel and bare soil).

Field plots were systematically sampled using random starting points for selecting the first of four transects in each plot and for selecting the first of five sighting frame positions on each transect. A sample size of 20 sighting frame positions per plot was determined to be adequate for a desired absolute precision of $\pm 5 \%$ (Waugh 1989). A $25-\mathrm{cm}$ area around the inside perimeter of each field plot was excluded from sampling to avoid treatment boundary effects. Sample means 
and variances were approximated using standard formulas for simple random sampling.

Analysis of variance (ANOVA) procedures were applied to these cover data, and the decision to reject or accept a hypothesis 1 or 3 (see Section 2.1) was based on an F-test. ANOVA involves partitioning the sum of squares of deviations of the response measurements about their mean. ANOVA statistically judges the significance of the variation among sample means by comparing it with a measure of the random variation within the population data (the variation within sample means). Effects on plant cover were analyzed using the following reduced splitplot ANOVA model:

$$
Y_{i j m}=u+R_{i}+P_{j}+e_{i j}+G_{m}+(P G)_{j m}+e_{i j m}
$$

where

$$
\begin{aligned}
& Y_{\mathrm{ijm}}=\text { plant measurement taken on plot that has assigned to it } \\
& \text { replication } \mathrm{i} \text {, irrigation level } \mathrm{j} \text {, and gravel admix treatment } \mathrm{m} \\
& \mathrm{u}=\text { overall mean } \\
& \mathrm{R}_{\mathrm{i}} \quad=\text { replication effect for level } \mathrm{i} \text {, where } \mathrm{i}=1,2,3 \\
& P_{j} \quad=\text { irrigation effect for level } \mathrm{j} \text {, where } \mathrm{j}=1,2 \\
& \mathrm{G}_{\mathrm{m}} \quad=\text { gravel admix effect for treatment } \mathrm{m} \text {, where } \mathrm{m}=1,2,3 \\
& (P G)_{j m}=\text { interaction effect of irrigation level } \mathrm{j} \text { and gravel admix treatment } \mathrm{m} \\
& e_{i j} \quad=\text { error for whole plot effects } \\
& e_{i j m}=\text { error for split-plot effects. }
\end{aligned}
$$

Because treatment replication interaction effects are excluded, the reduced model gives approximate F-tests, but with many more degrees of freedom than a full model that includes treatment interaction effects. Mean comparisons were performed using Duncan's Multiple Range Test $(p<0.05)$.

\subsection{RESULTS AND DISCUSSION}

Figure 6.1 depicts the comparisons of plant cover among years; between water treatments, and among gravel admix treatments. Surface gravel cover, also 

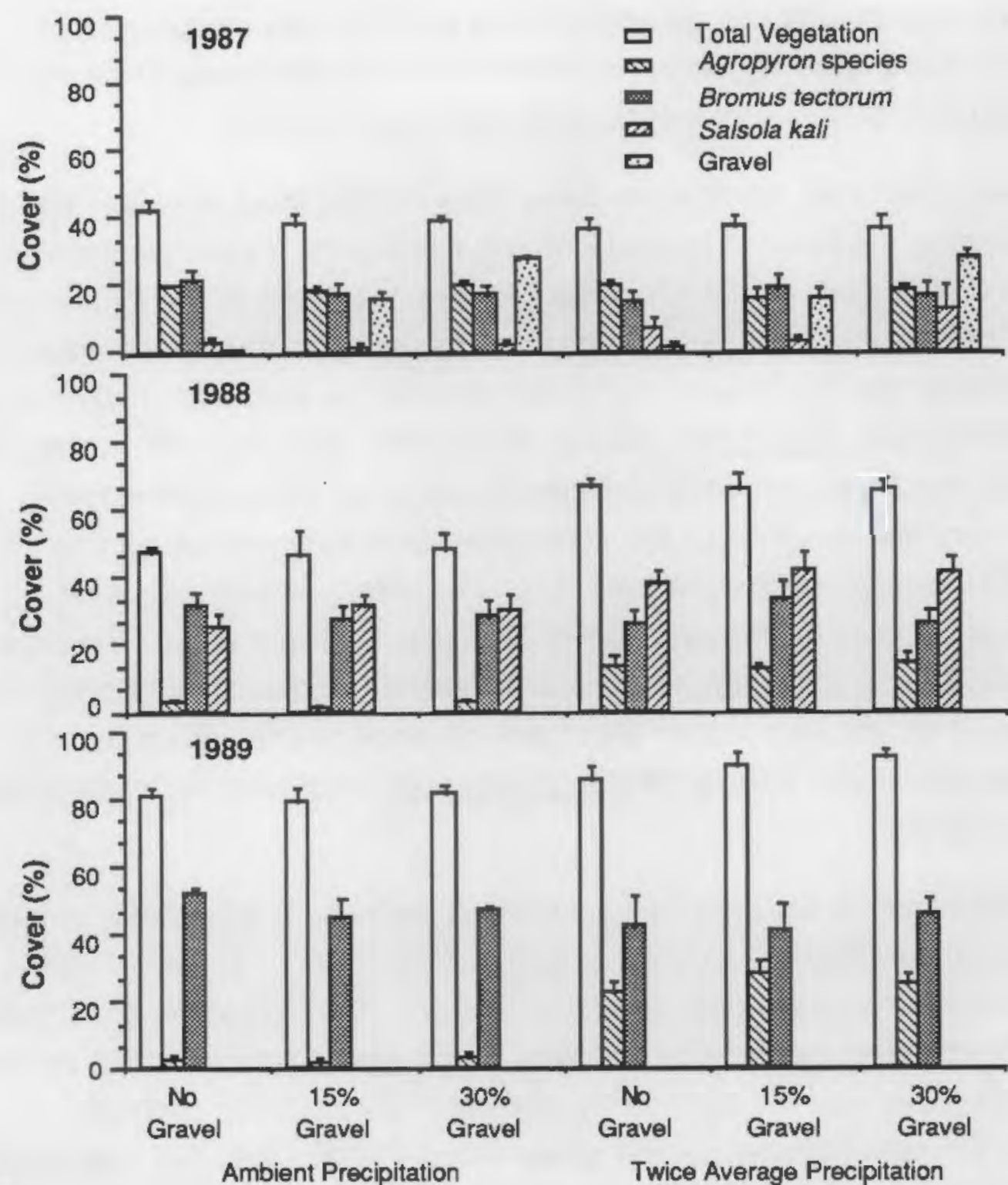

FIGURE 6.1. Percentage Cover by Cover Class (Total Vegetation, Agropyron Species, Bromus tectorum, Salsola kali, and Gravel) for 1987, 1988, and 1989 in Plots that were Treated with $15 \%, 30 \%$, or No Gravel Admixture and then Either Irrigated or Not Irrigated. Values are mean \pm standard error. Means within cover classes and years, and with the same letter, are not significantly different $(n=3)$.

shown, matches the applied levels of percent by weight admixture. Overall, yearly changes in cover and the influence of added water were significant. However, the gravel admixture treatments had no significant effect on plant cover. In reference to the hypotheses set forth in Section 2.1 (page 3), based on these results, we accept hypothesis 1 and reject hypothesis 3 . Additions of gravel mixed into the topsoil 
layer of the protective barrier did not influence plant species composition or abundance (hypothesis 1). However, the twice annual precipitation treatment influenced plant species composition and cover (hypothesis 3 ).

Total plant cover (sampled in June) more than doubled between 1987 and 1989. Doubling the average precipitation resulted in $20 \%$ greater plant cover in 1988 ( $p<0.05)$, although the difference between irrigated and nonirrigated plots was considerably less in 1989 , perhaps as a consequence of an abnormally wet spring. Greater total plant cover in irrigated plots can be attributed primarily to the seeded wheatgrass (Agropyron) species (Figure 6.1). Seeded in September 1986, wheatgrass seedlings were fairly well established on all plots by June 1987 . However, very few seedlings on the nonirrigated plots survived the summer drought, as indicated in the June 1988 data. In contrast, wheatgrass cover continued to increase on irrigated plots in 1988 and $1989(p<0.05)$. The cover of cheatgrass (Bromus tectorum), which was not seeded, also increased over the 3 years. However, irrigation had no significant influence on cheatgrass cover ( $p<$ 0.05). The response of Russian thistle (Salsola kali), another invader, paralleled that of cheatgrass.

These findings are in agreement with the preliminary results of a companion study in which the effects of a variety of surface treatments on soil water balance are measured in lysimeters (Waugh and Link 1987). The biomass of cheatgrass seeded on lysimeters treated with a $30 \%$ by weight gravel admixture and on those receiving no gravel was not significantly different (Figure 6.2). In contrast, cheatgrass biomass from the surface gravel mulch was less than half that from the no gravel treatment. Because biomass is closely related to leaf area and evapotranspiration, the combined preliminary findings of these studies suggest that plant growth and water extraction will be less influenced by an admixture than by a surface mulch. Therefore, if the wind and runoff erosion tests show that gravel additions are necessary for erosion control, and if all other effects are found to be equal, an admixture may be the preferred design. A more definitive recommendation will be possible following the analysis of water storage data in FY 1990. 


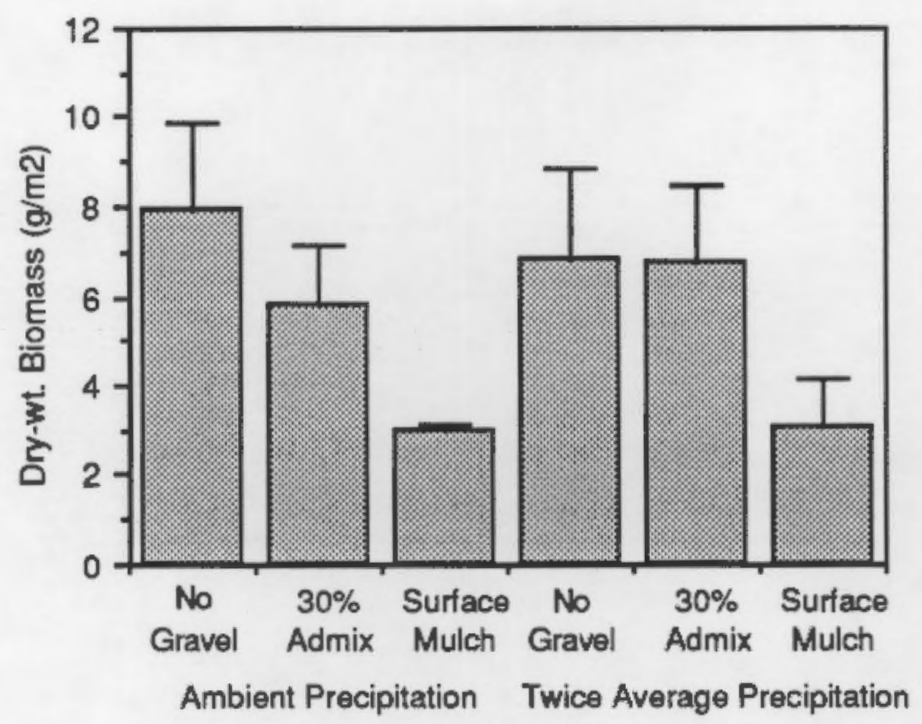

FIGURE 6.2. Dry Weight Biomass of Cheatgrass for May 1989 in Lysimeters Treated with $30 \%$ Gravel Admixture (by wt), an Equivalent Amount of Surface Gravel Mulch, or No Gravel, and then Either Irrigated at a Rate Twice the Long-Term Average Precipitation or Not Irrigated. Values are mean \pm standard error, $n=5$. Means with the same letter are not significantly different. 



\subsection{REFERENCES}

Blake, G.R., and K.A. Hartge. 1986. "Chapter 13: Bulk Density." In Methods for Soil Analysis. Part 1: Physical and Mineralogical Methods, 2nd ed., ed. A. Klute, American Society of Agronomy, Madison, Wisconsin.

Evans, D. D., and J. L. Thames. 1981. "Desert Hydrologic System." In Water in Desert Ecosystems, eds. D. D. Evans and J. L. Thames, pp. 265-272. Dowden, Hutchinson and Ross, Inc., Stroudsburg, Pennsylvania.

Evans, D. D., T. W. Sammis, and D. R. Cable. 1981. "Actual Evapotranspiration Under Desert Conditions." In Water in Desert Ecosystems, eds. D. D. Evans and J. L. Thames, pp. 195-218. Dowden, Hutchinson and Ross, Inc., Stroudsburg, Pennsylvania.

Fayer, M. J., W. Conbere, P. R. Heller, and G. W. Gee. 1985. Model Assessment of Protective Barrier Designs. PNL-5604, Pacific Northwest Laboratory, Richland, Washington.

Floyd, D. A., and J. E. Anderson. 1983. "A Comparison of Three Methods for Estimating Vegetal Cover." In Idaho National Engineering Laboratory Radioecology and Ecology Programs. 1983 Progress Report, DOE/ID-12098, U.S. Department of Energy, Idaho Falls, Idaho.

Gardner, W. H. 1986. "Water Content." In Methods of Soil Analysis, Part 1, ed. A. Klute, Second Ed., American Society of Agronomy, Madison, Wisconsin.

Gee, G. W., R. R. Kirkham, J. L. Downs, and M. D. Campbell. 1989. The Field Lysimeter Test Facility (FLTF) at the Hanford Site: Installation and Initial Tests. PNL-6810, Pacific Northwest Laboratory, Richland, Washington.

Kinnison, R. R. 1983. Apolied Extreme Value Statistics. PNL-4696, Pacific Northwest Laboratory, Richland, Washington.

Kirkham, R. R., and G. W. Gee. 1987. An Experimental Plan for the Field Lysimeter Test Facility. PNL-6351, Pacific Northwest Laboratory, Richland, Washington.

Ligotke, M. W. 1989. Surface Stability Test Plan for Protective Barriers. PNL6722, Pacific Northwest Laboratory, Richland, Washington.

Link, S. O., and W. J. Waugh. 1989. Evapotranspiration Studies for Protective Barriers: Experimental Plans. PNL-6899, Pacific Northwest Laboratory, Richland, Washington.

Mabbutt, J. A. 1977. Desert Landforms: An Introduction to Systematic Geomorphology, Vol.2. The MIT Press, Cambridge, Massachusetts.

Milliken, G. A., and D. E. Johnson. 1984. Analysis of Messy Data: Designed Experiments. Lifetime Learning Publications, Belmont, California. 
Myers, D. R. 1987. Disposal Materials Study. RHO-WM-EV-12P, Rockwell Hanford Operations, Richland, Washington.

Nichols, J. D., P. L. Brown and W. J. Grant (eds.). 1984. Erosion and Productivity of Soils Containing Rock Fragments. SSSA Special Pub. No. 13, Soil Science Society of America, Madison, Wisconsin.

Odum, E. P. 1969. "The Strategy of Ecosystem Development." Science 164:262270.

Richards, L. A. 1931. "Capillary Conduction of Liquids in Porous Mediums." Physics 1:318-333.

SAS Institute. 1985. SAS User's Guide: Statistics, Version 5 Edition. SAS Institute inc. Cary, North Carolina.

Stone, W. A., J. M. Thorp, O. P. Gifford, and D. J. Hoitink. 1983. Climatological Summany for the Hanford Area. BNWL-4622, Pacific Northwest Laboratory, Richland, Washington.

U.S. Department of Energy (USDOE). 1987. Final Environmental Impact Statement Disposal of Hanford Defense High-Level. Transuranic and Tank Wastes. DOE/EIS- 0113, U.S. Department of Energy, Washington, D.C.

Walters, W. H., K. A. Hoover, and L. L. Cadwell. 1990. Project Test Plan for Runoff and Erosion on Fine-Soil Barrier Surfaces and Rock-Covered Side Slopes. PNL6791, Pacific Northwest Laboratory, Richland, Washington.

Waugh, W. J. 1989. Gravel Admix. Vegetation, and Soll Water Interactions in Protective Barriers: Experimental Design, Construction, and Initial Conditions. PNL-6616, Pacific Northwest Laboratory, Richland, Washington.

Waugh, W. J., and S. O. Link. 1987. Barrier Erosion Control Test Plan: Gravel Mulch. Vegetation and Soil-Water Interactions. WHC-EP-0067, Westinghouse Hanford Company, Richland, Washington. 


\section{DISTRIBUTION}

No. of

copies

\section{OFFSITE}

2 DOE/Office of Scientific and Technical Information

2 Jacobs Engineering Group, Inc. 5301 Central Avenue NE Suite 1700

Albuquerque, NM 87108

ATTN: N. B. Larson

C. Reith

3 Los Alamos National Laboratory P. O. Box 1663

Los Alamos, NM 87545

ATTN: T. E. Hakonson

J. W. Nyham

F. Barnes

2 U. S. Ecology

P. O. Box 7246

9200 Shelbyville Rd

Suite 526

Louisville, KY 40207

ATTN: R. E. Sauer

D. Lane

2 U. S. Nuclear Regulatory Commission

Division of Engineering Safety

MS NL-005

Washington, DC 20555

ATTN: E. O'Donnell

T. J. Nicholson

W. Brewer

Office of High-Level Nuclear Waste Management

Washington State Department of Ecology

Olympia, WA 98504
No. of

Copies
A. J. Busacca

Agronomy Department

Washington State University

Pullman, WA 99164

G. S. Campbell

Agronomy Department

Washington State University

Pullman, WA 99164

E. M. Carlin

Low-Level Radioactive Waste Program

Washington Department of Ecology

Mail Stop PV-11

Olympia, WA 98504

Jack Duray

UNC Geotech

P.O. Box 14000

Grand Junction, CO 81502

John Elmer

UNC Geotech

P.O. Box 14000

Grand Junction, CO 81502

O. D. Markham

U. S. Department of Energy

785 DOE Place

idaho Falls, ID 83402

C. Massimino

U. S. Environmental Protection Agency

1200 Sixth Avenue

Seattle, WA 98101

Peter J. Mehringer

Anthropology Department

Washington State University

Pullman, WA 99164 


\section{DISTRIBUTION}

No. of

Copies

Jerry Olson

U.S. Bureau of Mines

Spokane Research Center

East Montgomery

Spokane, WA 99207

Alan Rainey

Radiation Protection Division

Airdustrial Park

Bldg. 5, M.S. LE-13

Olympia, WA 98504

J. Rensel

High-Level Waste Management

Washington State Department of Ecology

Mail Stop Pu II

Olympia, WA 98504

T. E. Reynolds

U. S. Department of Energy

785 DOE Place

Idaho Falls, ID 83402

Vince Tonc

UNC Geotech

P.O. Box 14000

Grand Junction, CO 81502

W. J. Waugh

UNC Geotech

P. O. Box 14000

Grand Junction, CO 81502

\section{FOREIGN}

P. Grimwood

Waste Management Unit

British Nuclear Fuels plc

Sellafield

Seascale, Cumbria CA201PG

ENGLAND
No. of

Copies

Graham M. Smith

Environmental Sciences Group

Intera-Exploration Consultants Ltd.

Highlands Farm, Greys Road

Henley-on-Thames

Oxon RG94PS

ENGLAND

\section{ONSITE}

7 DQE Richland Operations Office

G. J. Braken

J. J. Broderick

R. D. Freeburg

M. J. Furman

R. E. Gerton

R. D. Izatt

J.P. Sands

1 EPA - Hanford Project Office

D. R. Sherwood, A7-70

33 Westinghouse Hanford Company

M. R. Adams

H. Babad

J. D. Berger

L. C. Brown

J. W. Cammann

R. A. Carlson

H. F. Daugherty

J. D. Davis

C. J. Geier

W. F. Heine

J. M. Henderson

G. W. Jackson

K. N. Jordan

C. J. Kemp

D. S. Landeen

R. E. Lerch

H. E. McGuire

D. R. Myers 


\section{DISTRIBUTION}

No. of

copies

B. E. Opitz

K. L. Petersen

S. J. Phillips

R. C. Roos

M. R. Sackschewsky

J. L. Scott

J. C. Sonnichsen

D. R. Speer

J. A. Voogd

S. A. Weigman

G. W. Williamson

N. R. Wing

D. D. Wodrich

R. D. Wojtasek

D. E. Wood

58 Pacific Northwest Laboratory

L. L. Cadwell (20)

M. D. Campbell

J. C. Chatters

J. L. Downs

L. E. Eberhardt

J. W. Falco

M. J. Fayer

M. G. Foley

H. D. Freeman

G. W. Gee

J. M. Hales

P. C. Hays

K. A. Hoover

C. T. Kincaid

R. R. Kirkham

G. V. Last

M. W. Ligotke

S. O. Link

R. W. Nelson

W. T. Pennell

W. H. Rickard

M. L. Rockhold

L. E. Rogers

M. A. Simmons

R. L. Skaggs

D. L. Stewart
No. of

Copies

T. L. Stewart

J. A. Stottlemyre

G. P. Streile

M. E. Thiede

J. M. Thomas

W. H. Walters

R. E. Wildung

Publishing Coordination

Technical Report Files (5) 
、

,

. 